\title{
60. THE LATE TERTIARY OF THE COASTAL PLAIN AND CONTINENTAL SHELF OF ISRAEL AND ITS BEARING ON THE HISTORY OF THE EASTERN MEDITERRANEAN
}

\author{
Gdaliahu Gvirtzman and Binyamin Buchbinder, Oil Research Division, \\ Geological Survey of Israel, Jerusalem, Israel
}

\begin{abstract}
A detailed study of the late Tertiary in the coastal plain and the continental shelf of Israel from deep boreholes and seismic surveys enabled us to reconstruct the geological history of the eastern Mediterranean. During the late Eocene, the Oligocene, and until the termination of the Burdigalian, open marine marls were deposited. Small-scale folding movements took place, mainly during the Oligocene. On some shallow anticlinal shoals, calcareous bioclastic sedimentation prevailed since Oligocene times. About 16 m.y.B.P., by the end of the Burdigalian, intense faulting took place and the Arabian and African platforms were uplifted about 1000 meters above sea level along the Levant fault system. This system includes longitudinal step faults which roughly coincide with the present coastline of Syria, Lebanon, Israel, and Sinai. The uplifted platforms were incised by rivers and deep erosional canyons formed. A new, restricted, transgression penetrated the canyon mouths and deposited open marine marls. This transgression was followed by renewed emergence of the Arabian Platform up to 2000 meters above sea level which resulted in the withdrawal of the sea far to the west of the present continental shelf and in the rejuvenation of the previous drainage systems. Successive subsidence was accompanied by another more extensive transgression during the Tortonian, about 9 m.y.B.P., and a new sedimentary cycle began. The sea covered the platform and deposited bioclastic limestones and coral reefs over the pre-existing erosional topography. This transgression was terminated about 7 m.y.B.P. The following Messianian regression and desiccation, 7 to 5 m.y.B.P., began with the withdrawal of the sea from the platform and slope, again as the result of tectonic uplift, while normal seawater remained in the central, relatively shallow Mediterranean Basin. At this stage nodular anhydrite and minor salt beds of coastal sabkha origin were deposited parallel to the regressive shoreline. Ultimately, the anhydrite was covered by fluvial clastic sediments. This regressive event was followed by the isolation of the Mediterranean Sea from the global ocean system and by the development of sodium and potassium depositing salt lakes in the central depressions. The Levant and Herodotus salt lakes, which were formed in the eastern Mediterranean Basin, were supplied by rivers which flowed from the Arabian and African platforms. These included the Nile River, surplus waters from the Paratethys lakes, and probably to a limited degree seepage brines derived from seawater. The hydrologic regime of these salt lakes during this stage closely resembles the Pleistocene and Recent setting of the Dead Sea. The evidence gathered from the eastern Mediterranean may indicate that water from the Paratethys lakes together with a relatively minor influx from the Nile River could have supplied the bulk of the salt deposited in this area.

During the Pliocene, 5 m.y.B.P. and later, the Mediterranean was again flooded and the Arabian Platform was resubmerged. The Pliocene sea penetrated deeply inland through the pre-existing erosional canyons and into the Jordan rift valley. The Gulf of Elat may have served as a possible connection between the Red Sea and the Mediterranean. The Recent topography of the eastern Mediterranean region was established during the Pleistocene as the result of additional subsidence of the Levant plate and the extensive accumulation of fine-grained sediments in the huge cone of the Nile Delta.
\end{abstract}


We do not believe that the model of a very deep and dry opening in the earth's crust during the Messinian, with repeated desiccations and successive refilling of the trough through the Gate of Gibraltar, which was proposed in Volume 13 of the Initial Reports of the Deep Sea Drilling Project, applies.

From data in the eastern Mediterranean region, the Messinian desiccation basin appears to have been relatively shallow. The number of marine intercalations in the evaporite sequence is variable and they cannot be correlated between different boreholes even a short distance apart which thus indicates that they do not represent repeated synchronous refill of the desiccated Mediterranean with marine water. These intercalations probably resulted from sea-level oscillations during a general single regressive trend.

\section{INTRODUCTION AND BACKGROUND}

\section{Previous Studies}

The late Tertiary strata of the coastal plain and the continental shelf of Israel are included in a comprehensive lithostratigraphic unit named the Saqiye Group which represents the late Eocene to early Pleistocene. The Saqiye Group forms a sedimentary prism along the coastal plain and continental shelf and its sediments thicken considerably westward. Patchy outcrops are found in the eastern part of the coastal plain, and the main body of the Saqiye Group is concealed by Quaternary sandstones and soils.

The intensive drilling activity for oil prospecting in the coastal plain and continental shelf during the fifties and sixties was followed by many recent studies which deal with stratigraphy, geological mapping on the basis of well logs, and geological interpretations of geophysical surveys. Although many of the earlier concepts were revised as a result of new data furnished by the intensive exploration and the improved seismic records, some of the earlier concepts still retain their importance. The following works deal mainly with regional studies and general paleogeographical reconstruction: Grader (1958), Picard (1959), Neev (1960), Reiss (1968), Gvirtzman (1970), Buchbinder (1975a), Neev et al. (1976). The works dealing mainly with paleontological and biostratigraphic concepts include: Reiss and Gvirtzman (1962, 1966a, 1966b); Moshkovitz (1963, 1968); Perath (1965); Avnimelech (1966); Rothmann (1967); Reiss (1968); Derin and Reiss (1973). Lithostratigraphic and sedimentological studies include: Grader and Gvirtzman (1961); Pomerancblum et al. (1962), Gvirtzman and Reiss (1965), Buchbinder (1975a). Studies of outcrop and mapping include: Gvirtzman and Buchbinder (1969), Gvirtzman (1969a). Studies based on geophysical interpretations include: Ginzburg et al. (1975), Neev et al. (1973, 1976).

The area studied in this work includes the southeastern corner of the Mediterranean and especially the coastal plain and the continental shelf of Israel (Figures 1,2 ).

\section{The Saqiye Group (late Eocene to early Pleistocene)}

During most of the Cretaceous through the middle Eocene, Israel was submerged under a relatively shal- low sea which deposited limestones, dolomites, and chalks known as the "Middle Calcareous Division" (Ball and Ball, 1953; Said, 1962). Toward the end of the middle Eocene, the area of Israel, the neighboring countries, and the adjacent continental shelf emerged. The transgressive clastic sediments, which begin the "Upper Clastic Division" (Ball and Ball, 1953; Said, 1962), unconformably overlie older Cretaceous and Tertiary sediments. The thick sedimentary sequence of late Eocene to early Pleistocene age is the Saqiye Group (Lowengart, 1927; Gvirtzman and Reiss, 1965, Reiss and Gvirtzman, 1966a; Gvirtzman, 1970). It consists mostly of thick, marly units with thin intercalations of reefal and bioclastic limestones, sandstones, conglomerates, and evaporites.

The thickness of the Saqiye Group varies from several meters in the eastern coastal plain to hundreds and even thousands of meters in the western coastal plain and the continental shelf. It is overlain by late Pliocene and Pleistocene calcareous sandstones of marine and eolian origin and is interbedded with fossil soils known as the "Kurkar Group." The Saqiye Group is commonly subdivided into sedimentary cycles representing transgressions and regressions and separated by erosional unconformity surfaces.

\section{Biostratigraphy, Chronostratigraphy, and Absolute Ages of the Saqiye Group}

The biostratigraphic subdivision of the Saqiye Group and the chronostratigraphy in terms of the Mediterranean stages and substages has been developed and modified since 1962 (Reiss and Gvirtzman, 1962, 1966a, 1966b; Reiss, 1968; Derin and Reiss, 1973). The last revision of Derin and Reiss (1973) forms the biostratigraphic foundation for our study. Figure 3 displays the biostratigraphic units 1, 2, 3, 4m1 and $4 \mathrm{~m} 2$ used in Israel. This biostratigraphic subdivision is not as detailed as that of the Atlantic and the western Mediterranean provinces (in which most of the units of Blow, 1969, are recognized) since many diagnostic foraminifera are rare or entirely missing from the Neogene of the eastern Mediterranean Basin. The absolute age of the foraminiferal datum levels (Fig. 3) are adopted from Ryan et al. (1974). This chronologic scale is preferred over other published scales because of its comprehensive use of the interrelationships among paleomagnetic polarity changes, rate of oceanic 


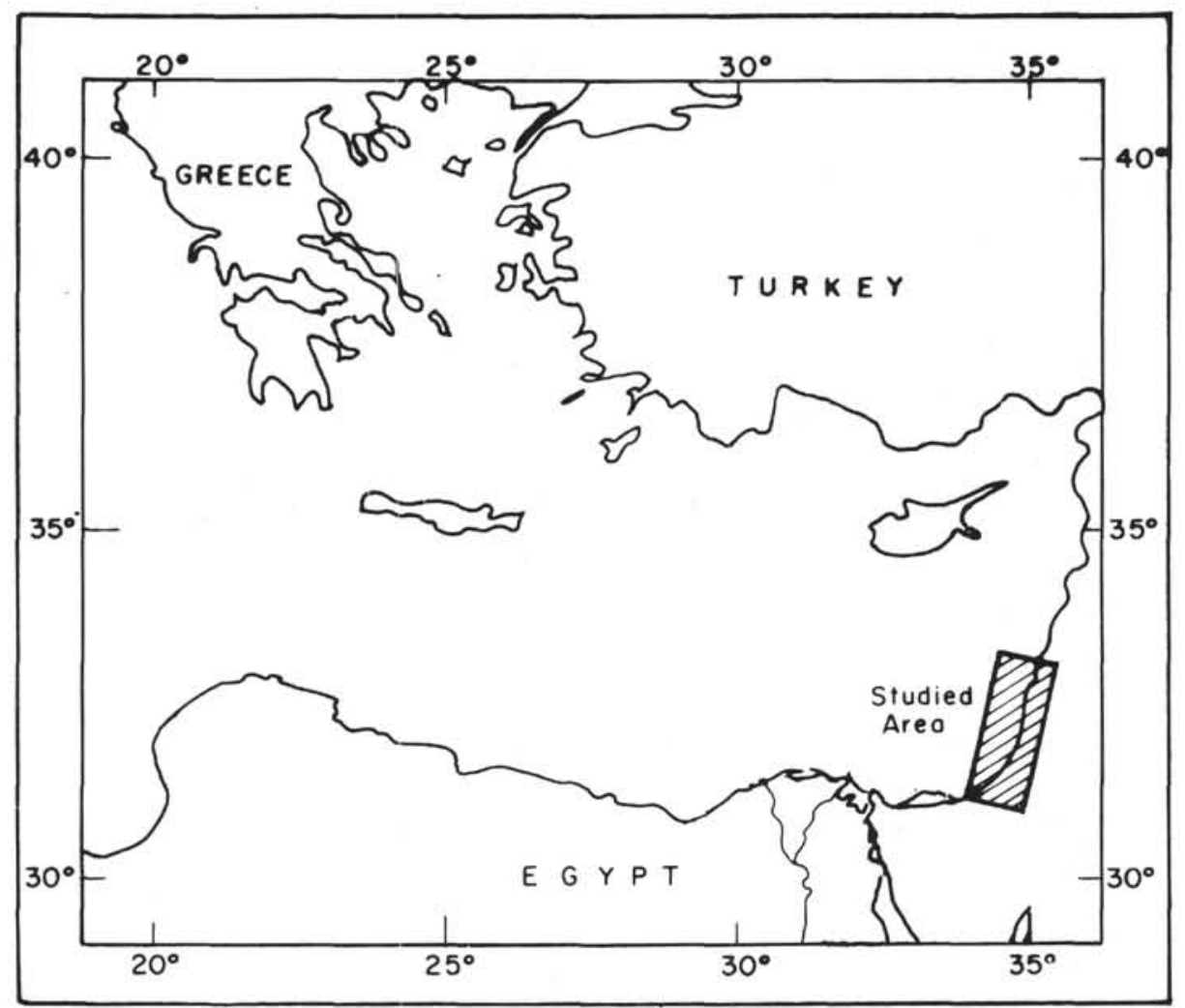

Figure 1. The studied area, the southeastern corner of the Mediterranean.

sea-floor spreading, rate of sedimentation of biogenous ooze, biostratigraphic zonation of DSDP cores, and comparison with the Italian stratotypes. The chronology of the few datum levels used in Israel, which are not dated by Ryan et al. (1974), is taken from Berggren and Van Couvering (1974). The following datum levels are the most important in the biostratigraphic subdivision in Israel.

1) The first appearance of $G$. angulisuturalis is 30 m.y.B.P. (Berggren and Van Couvering, 1974, p. 170).

2) The first appearance of Globigerinoides, which marks the base of Unit 2, is 25 m.y.B.P. (Berggren and Van Couvering, 1974, in the revised appendix, p. 170not 22.5 m.y.B.P. as stated on p. 12 of the main paper).

3) The first appearance of Orbulina suturalis, which marks the base of Unit 3, is 16 m.y.B.P. (Ryan et al., 1974).

4) The first appearance of $G$. nepenthes, which marks the base of Unit $4 \mathrm{ml}$, is 12.7 m.y.B.P. (Ryan et al., 1974).

5) The extinction of G. mayeri, which marks the base of Unit $4 \mathrm{~m} 2$, is 12 m.y.B.P. (Ryan et al., 1974).

6) The first appearance of $G$. margaritae (s.s.) marks, according to Derin and Reiss (1973), the beginning of Unit $4 \mathrm{pl}$ and the Pliocene. Ryan et al. (1974) and Berggren and Van Couvering (1974) do not discuss the absolute age of this datum. However, since Derin and Reiss (1973) include the unit 4pl. within the unit N18 of Blow (1969), an age of 5.1 m.y.B.P. is implied.
7) The first appearance of Sphaeroidinella dehiscens, which marks the base of Unit $4 \mathrm{p} 2$, is 5.0 m.y.B.P. (Ryan et al., 1974).

8) The extinction of $G$. nepenthes, which marks the top of Unit 4p2, is 3.7 m.y.B.P. (Berggren and Van Couvering, 1974).

9) The first appearance of G. truncatulinoides, which marks the beginning of the Pleistocene, is 1.8 m.y.B.P. This foraminifer is also known from Israel; however, Derin and Reiss (1973) did not assign a biostratigraphic datum to its appearance.

The absolute ages of the biostratigraphic units of Blow (1969) and the boundaries of the stages and substages (Figure 3) were adopted following Ryan et al (1974). The correlation between the local biostratigraphic units and those of Blow (1969), differs slightly from the correlation of Derin and Reiss (1973). The matching of local lithostratigraphic units to the biostratigraphic and chronologic scheme is mainly on the basis of diagnostic foraminifera and partly on other geological evidence discussed in the following chapters.

\section{Utilization of Seismic Records}

Although the basis of this work is mainly the stratigraphic study of boreholes (Gvirtzman, 1969b), two main stratigraphic boundaries-the unconformity at the base Saqiye Group, and the Mavqiim anhydrite which separates the Miocene marls of the Ziqim and Bet Guvrin formations (Lower Saqiye Group) from the 


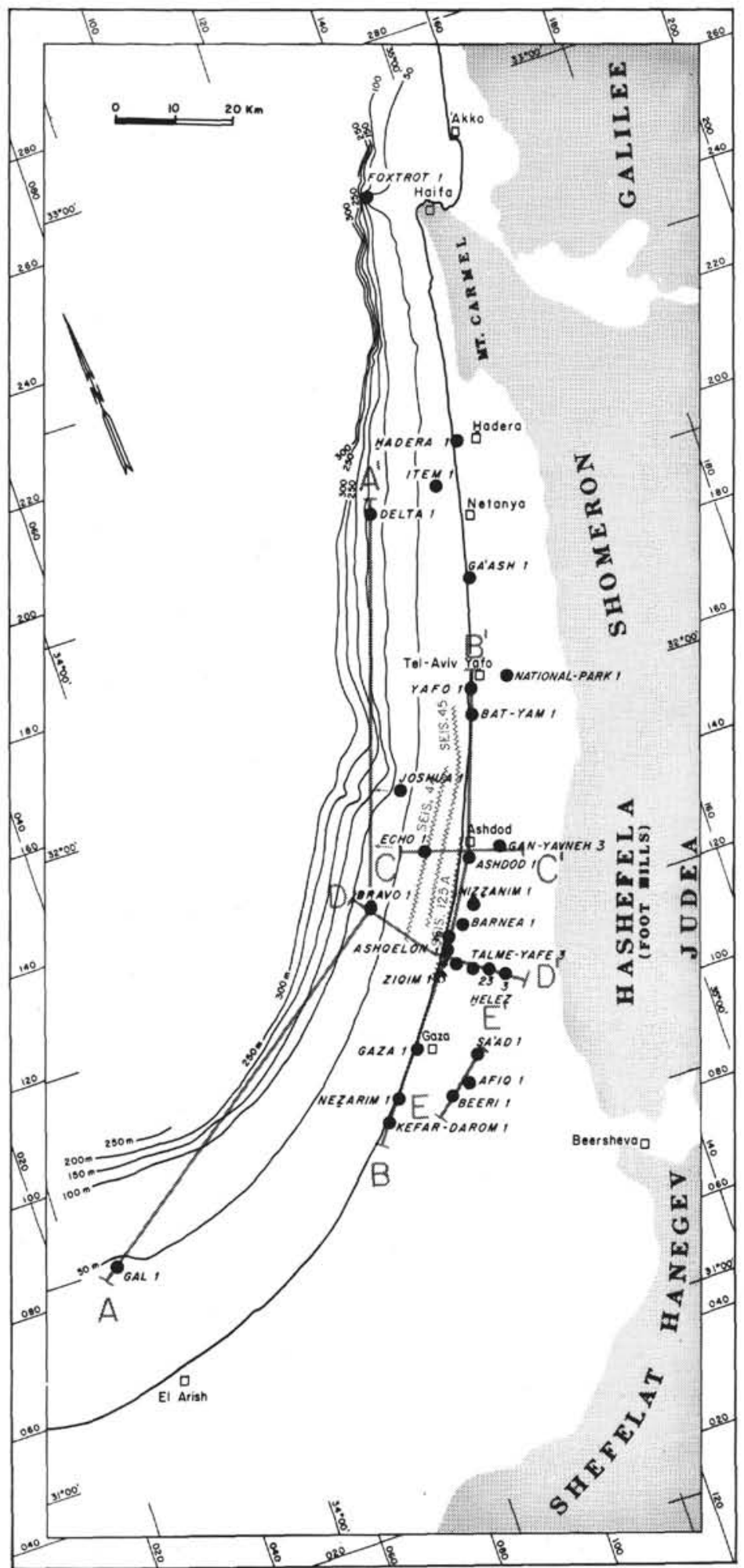

Figure 2. Location map of the coastal plain and the continental shelf of Israel, showing the location of drillholes, geological cross-sections $A-A^{\prime}$ to $E-E^{\prime}$, and seismic record sections 44 , 45 , and 125A. Shaded areas indicate hilly and mountainous regions. 


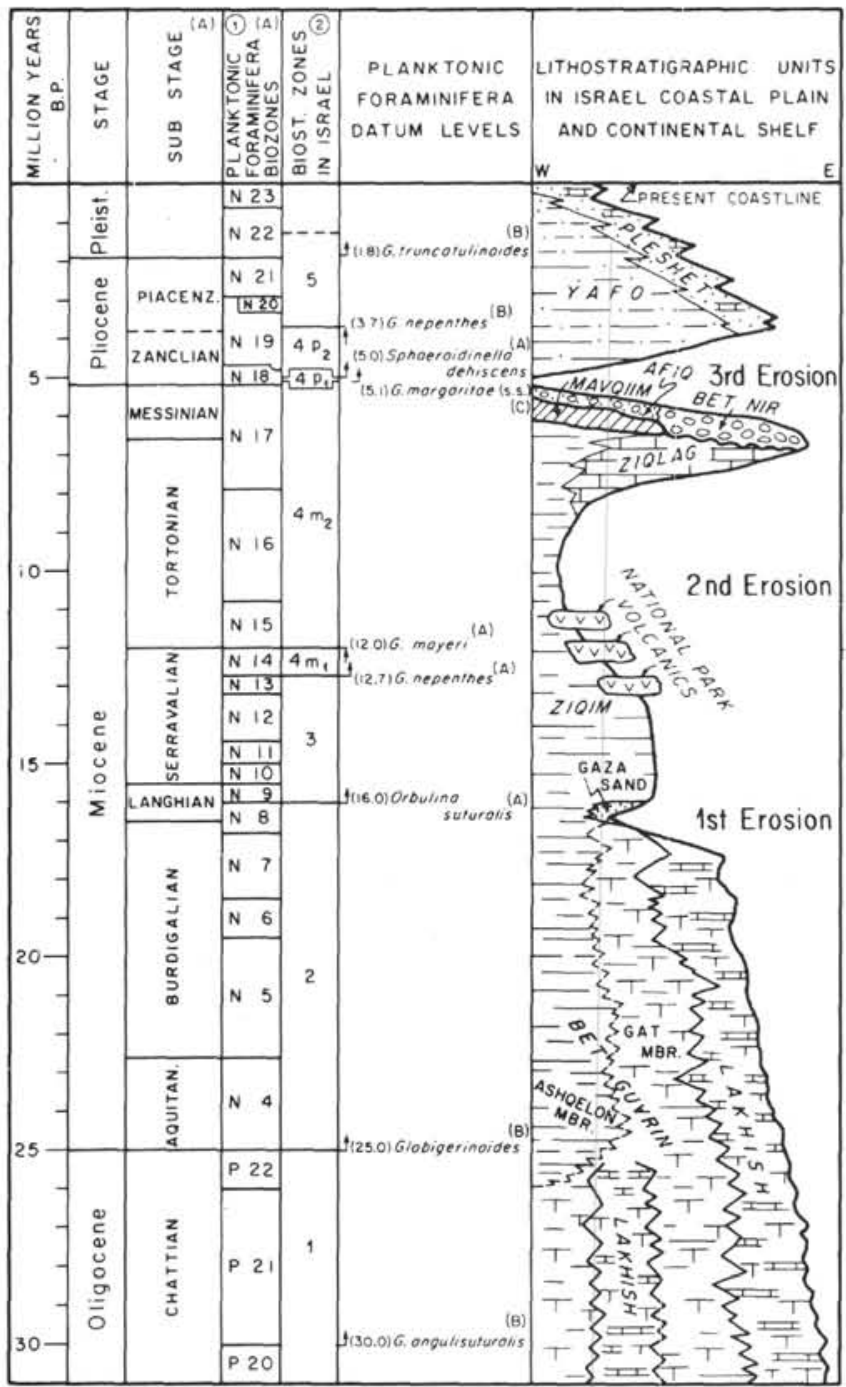

BIOSTRATIGAAPHIC UNITS AFTER: (1) BIOW 1969. (2) Derin and Reiss 1973, POSITION OF BOUNDARIES ANO DATUM LEVELS IN ABSOLUTE TIME SCALE AT TER: (A) Ryon ol ol 1974 (B) Berggren and van Couvering 1974 , (C) Derin and Reiss 1973

Figure 3. Stratigraphy of the Oligocene-Neogene in the coastal plain and continental shelf of Israel. Lithostratigraphic units are superimposed on a schematic west-east section perpendicular to the coastline. The stratigraphic sequence is divided into three erosional phases separating the Bet Guvrin, the Ziqim, the Ziqlag-Mavqiim, and the Yafo sedimentary cycles. Each cycle is defined by an eastward transgression and $a$ westward regression.

Pliocene Yafo marls (Upper Saqiye Group)-were expressed as seismic reflectors in the many seismic surveys run in the area.

Seismic velocity records were transferred into depth figures by Ginzburg et al. (1975) by utilization of either velocity surveys in boreholes, or velocity analyses of CDP (common depth point) traces. The interval velocity of the Upper Saqiye Group was 1620-1750 $\mathrm{m} / \mathrm{sec}$, and the Lower Saqiye Group was 2600-2700 $\mathrm{m} / \mathrm{sec}$ (Ginzburg et al., 1975).

\section{Tectonic Setting}

Figure 4 is a structural map on the unconformity surface at the base of the Saqiye Group. The contours presented in Figure 4 are restricted to the onshore area of the coastal plain. Although we did not attempt it in this study, the contours could be continued through the entire continental shelf on the basis of the many seismic surveys and the few boreholes drilled in this area. The erosional relief at the end of the middle Eocene was probably relatively gentle (Gvirtzman, 1970), and the present structural contours of this datum should, to a great extent, reflect tectonic movements post dating the middle Eocene, i.e., since the deposition of the Saqiye Group.

The area was tectonically differentiated into a platform in the east (designated herein as the Arabian Platform) and a slope to the west which continues into the Levant Basin. The elevation of the base Saqiye datum is -250 meters up to +250 meters in the western edge of the Arabian Platform. It was displaced by a series of longitudinal step faults down to a depth of -2000 to -2500 meters toward the Levant Basin. The longitudinal fault system is accompanied by a west-northwest transversal system of relatively short faults with a throw of tens of meters. This transverse fault system regulated the pattern of the drainage systems flowing into the basin. The longitudinal fault system probably continues northward parallel to the coasts of Lebanon and Syria, and to the south and west parallel to the Sinai coast, and toward the Nile Delta. In fact, Said (1973, 1975) described an east-west fault separating the Nile Delta into an upthrown southern block and downfaulted northern block. The age of the faulting phase is discussed below.

The tectonic differentiation of the area into a high platform and deep basin influenced the sedimentary regime during the deposition of the entire Saqiye Group. The system of the elongated faults parallels and partially coincides with an earlier Mesozoic "hinge line" which similarly separated a shallow shelf of the Arabian Platform from a continental slope and continental rise of the Tethys Sea (Gvirtzman and Klang, 1972; Bein, 1974; Druckman et al., 1975; Bein and Weiler, 1976).

\section{STRATIGRAPHIC AND PALEOGEOGRAPHIC RECONSTRUCTION}

\section{The Bet Guvrin Sedimentary Cycle (late Eocene- Burdigalian)}

\section{Stratigraphy}

General-The stratigraphy of the Bet Guvrin sedimentary cycle, as well as of successive cycles, was determined from detailed study of boreholes in the coastal plain and continental shelf of Israel. The lithostratigraphic subdivision and the correlation between the boreholes are illustrated in Figures 5, 6, 7, 8, 9 , and 10 .

The Bet Guvrin cycle is characterized by a continuous transgression over a gentle erosional plain. The transgression started during the late Eocene and flooded most of Israel and the entire margin of the Arabian Platform. The cycle was terminated during the Burdigalian (Figure 3 ) by a regression and tectonic 
G. GVIRTZMAN, B. BUCHBINDER

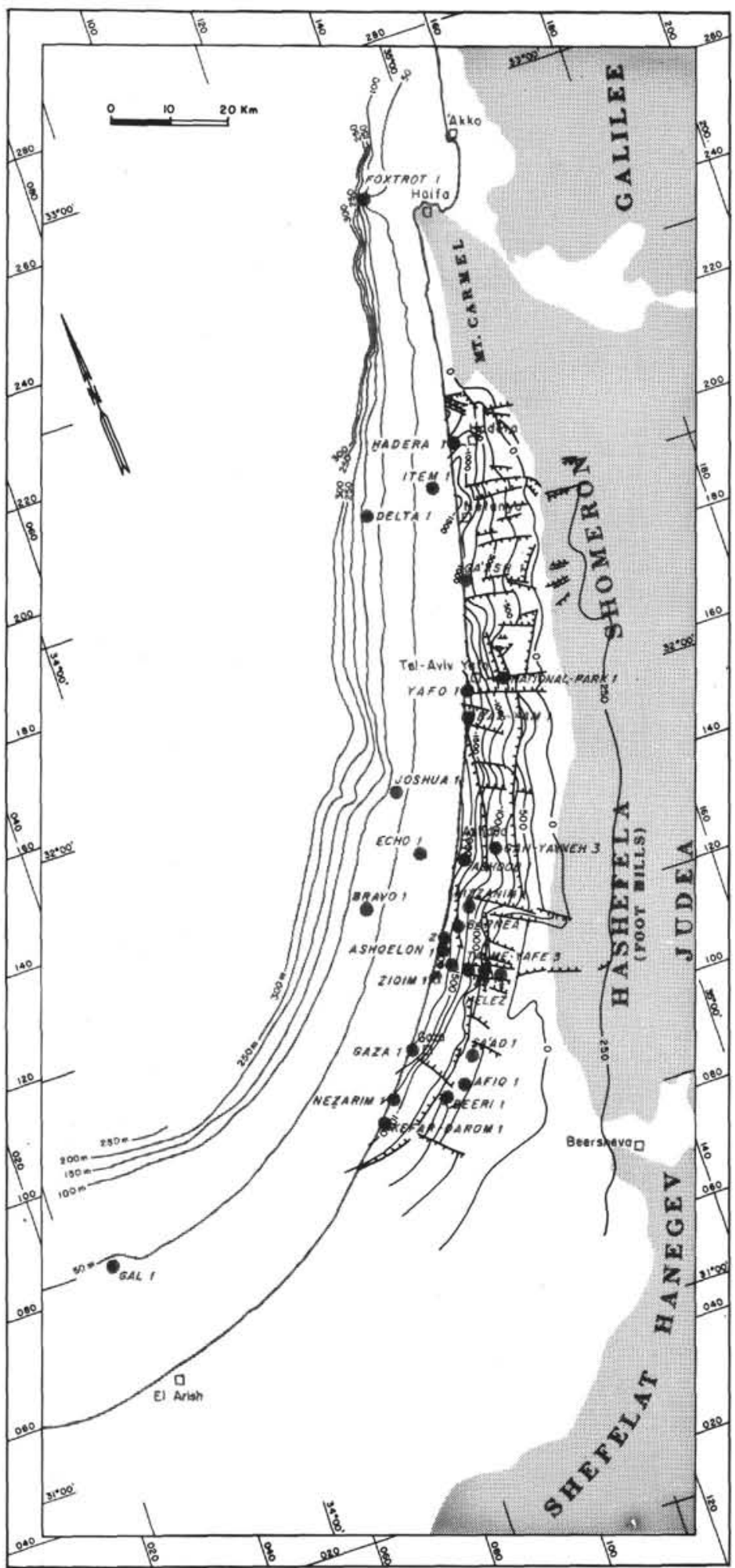

Figure 4. Structural contour map of the unconformity surface between the top of the Hashefela Group (middle Eocene or older) and the Saqiye Group (upper Eocene or younger). Contour interval, 250 meters. Modified after Gvirtzman (1969a). Longitudinal normal step faults accompanied by transverse faults separate the Arabian Platform in the east from the downfaulted Levant Basin to the west. The total vertical displacement is more than 2000 meters. 


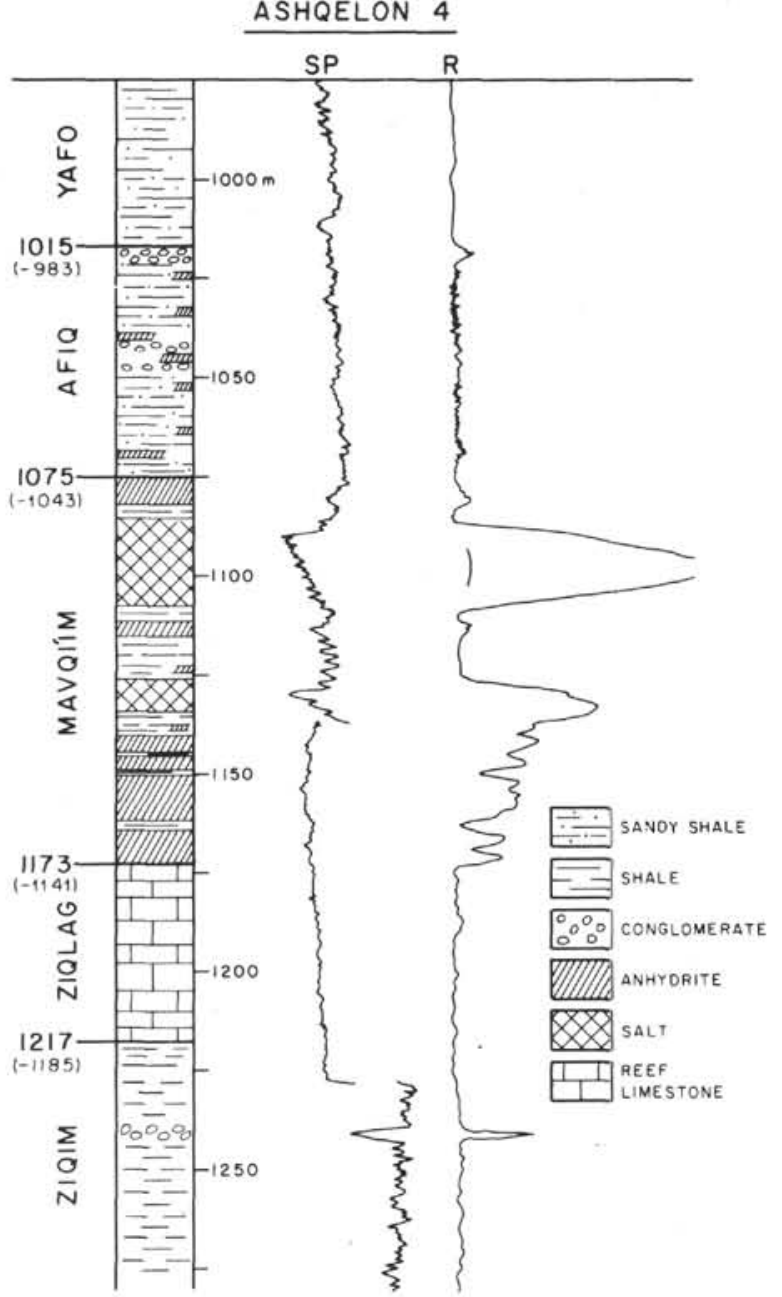

Figure 5. A representative section of Neogene formations in the coastal plain of Israel. Ashqelon 4 borehole, coord.: $E-108264, N-116015$, elevation (K.B.): 32 meters. The larger numbers to the left indicate the depth of the formation boundaries as penetrated in the boreholes. The numbers in parentheses show elevation relative to sea level. The Ziqim Formation consists of open-sea globigerina marls, the Ziqlag Formation of coral reef, the Mavqiim Formation of evaporites, the Afiq Formation of fluvial silts, sands, and conglomerates with some redeposited evaporites, and the Yafo Formation of open marine shales (for ages of the units see Figure 3).

movement along the coastal plain resulting in the differentiation of the rising Arabian Platform from the sinking Levant Basin. The Arabian Platform emerged and was intensively eroded while the sea remained in the basin to the west.

This cycle is characterized by gentle folding, especially during Oligocene times. The folding pattern is characterized by narrow anticlines and synclines with an amplitude of about 200 meters (Gvirtzman, 1970).

The Bet Guvrin Formation-Picard and Solomonica (1936) described outcrops of marls and chalks of upper Eocene to Oligocene age in the southeastern part of the coastal plain of Israel. A very thick sequence of these marls was later found subsurface. Their upper age limit is early Miocene (see emendation by Gvirtzman and Reiss, 1965).

The Bet Guvrin Formation is divided into two members. The lower Gat Member is found mainly in the east. It consists of slightly sandy and glauconitic yellowish gray, chalky marl. The upper Ashqelon Member overlies and passes laterally into the Gat Member. It is mainly found subsurface in the western part of the coastal plain. The Ashqelon Member formed only since late Oligocene. It consists of glauconitic greenish gray, clayey marl, and is very rich in planktonic foraminifera and in places becomes a globigerina ooze (Gvirtzman, 1970), Pteropods are occasionally present (Avnimelech, 1966).

The Bet Guvrin Formation includes the foraminifera zones of units UE (upper Eocene), 0, 1, and 2 (Reiss, in Reiss and Gvirtzman, 1966a). It unconformably overlies Cretaceous and Tertiary limestones and chalks. Onlap relations are found toward the anticlines, i.e., the lower biostratigraphic units are missing over the anticlinal crests. The top of the Bet Guvrin Formation is truncated in most of the coastal plain. Toward the western part of the coastal plain and the continental shelf, sedimentation continued into the LanghianSerravallian Ziqim Formation with a slight lithologic change. In places, for example, the $\mathrm{Gal} 1$ drillhole (Figure 6), the Bet Guvrin and Ziqim formations could not be differentiated.

The Lakhish Formation-(Gvirtzman and Buchbinder, in Gvirtzman and Reiss, 1965). In its lower part the formation consists of collapsed blocks and boulders of limestones and chalk embedded in skeletal calcarenites with abundant Operculina and Lepidocyclina tests, and molluscan and coralline algae debris. The upper part consists of massive bioclastic limestone with the same fauna and a few corals. Cox (1934) and Avnimelech (1936) determined that it was Oligocene in age on the basis of the larger foraminifera. The formation conformably overlies and also passes laterally into the Bet Guvrin Formation. It unconformably overlies other Tertiary formations. The top of the Lakhish Formation is always truncated. The formation varies in thickness from several meters to 170 meters. It is distributed in patches of a few square kilometers each. Deposition probably took place on elevated shoals (drillholes Bat Yam 1, Ashqelon 4, and Echo 1, see Figures 5-9) and was probably contemporaneous with the Oligocene folding (Gvirtzman, 1970), as indicated by slumping and collapse structures in the lower part of the formation. The Bet Guvrin Formation continued to be deposited simultaneously in the sinking synclines.

The deposition of the Lakhish Formation in the western coastal plain continued into the Burdigalian, as evidenced by interbedded marls containing foraminifera of Units 1 and 2.

\section{Paleogeographic Reconstruction}

The tectonic separation of the Arabian Platform from the Levant Basin and the first erosional phase (approximately 16 m.y.B.P.)-The main portion of this displacement took place within a short time during the 


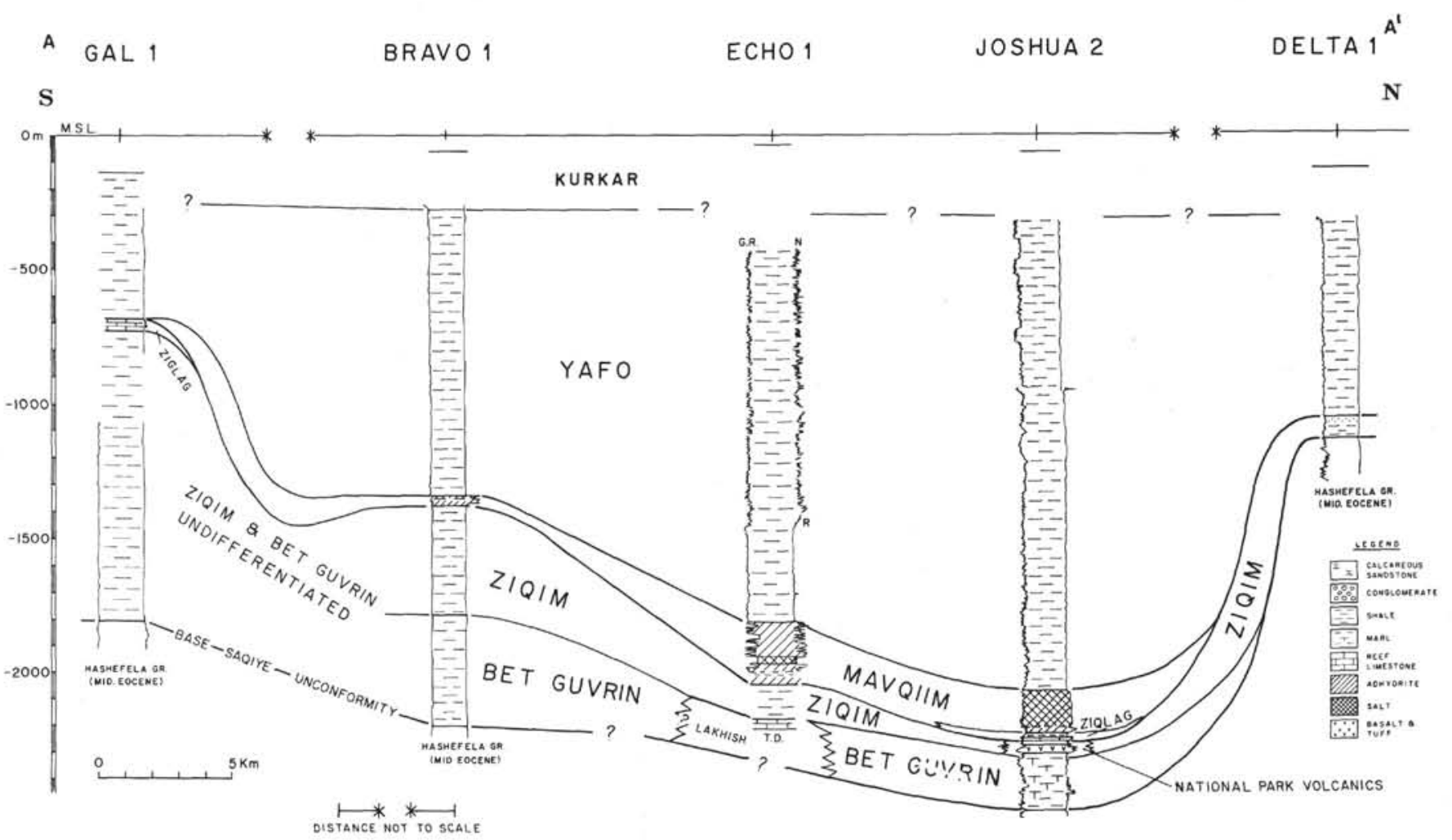

Figure 6. North-south stratigraphic cross-section A-A' along the continental shelf of Israel (for location, see Figure 2; for stratigraphic relationship, see Figure 3). Heavy line $=$ unconformity contact. The base Saqiye boundary is a regional erosional unconformity surface which separates middle Eocene or older chalks and limestones from late Eocene or younger marls and shales (Saqiye Group). The boundary between the Ziqim and Bet Guvrin formations is undifferentiated in the Gal 1 borehole.

Langhian after the deposition of the Bet Guvrin and Lakhish formations and before the deposition of the Ziqim Formation (i.e., about the time of the Orbulina datum, 16 m.y.B.P.). As a result, deep canyons were cut along the platform edges. The tectonic displacement took the form of longitudinal step faults roughly parallel to the present shoreline. Continuous marine conditions prevailed to the west of the faults. The following arguments support this interpretation.

1) The shallow marine Lakhish Formation developed on both sides of the step fault system, both on the platform and in the basin. In contrast, the Ziqim Formation (discussed below) only developed in the step fault zone and in the basin west of the platform edge. The top of the Ziqim is never higher than 600 meters below the present sea level-fairly well off the platform edge.

2) The unconformity surface between the Bet Guvrin and Lakhish formations and the overlying Ziqim Formation is marked by a huge canyon in the Afiq area (penetrated by the Afiq 1 borehole, Figure $10)$ and by similar smaller canyons at Ashdod and near Caesarea. The Afiq (or Gaza-Beer Sheva) canyon was cut by a river flowing from the central Negev via Beer Sheva to Gaza (Neev, 1960; Gvirtzman and Buchbinder, 1969; Gvirtzman, 1969a, 1970). The difference in elevation between the canyon shoulders and its bottom in the Afiq area is near 1000 meters. Since the canyon bed was above sea level during the time of its formation, it is conceivable that the differ- ence in elevation between the platform edge and sea level of that time exceeded 1000 meters. The cliff at the platform edge coincided more or less with the shoreline. The canyon was incised after the deposition of the Bet Guvrin Formation (Unit 2) which rests on its shoulders. But the incision predates the Ziqim Formation (with marine foraminifera of Unit 3 ), the first marine sediment found along the canyon's thalweg.

3) Whereas the unconformity surface at the base of the Ziqim Formation was found in drillholes close to the platform edge in the step fault scarp (Helez and Talme Yafe boreholes, Figure 9), to the west (Ashqelon boreholes, Figure 9), and in the offshore area, there is continuous sedimentation between the Bet Guvrin and Ziqim formations, which implies that after the tectonic displacement the sea remained in the downfault block area.

In conclusion, the longitudinal fault movements, the formation of the erosional canyons, and their relation to the Ziqim Formation attest to a simultaneous faulting and erosional event which occurred during a relatively short time about the time of the first appearance of Orbulina, 16 m.y.B.P.

\section{The Ziqim Sedimentary Cycle (Langhian- Serravallian)}

\section{Stratigraphy}

General-The Ziqim Formation was deposited during a limited marine transgression mainly in the basin 


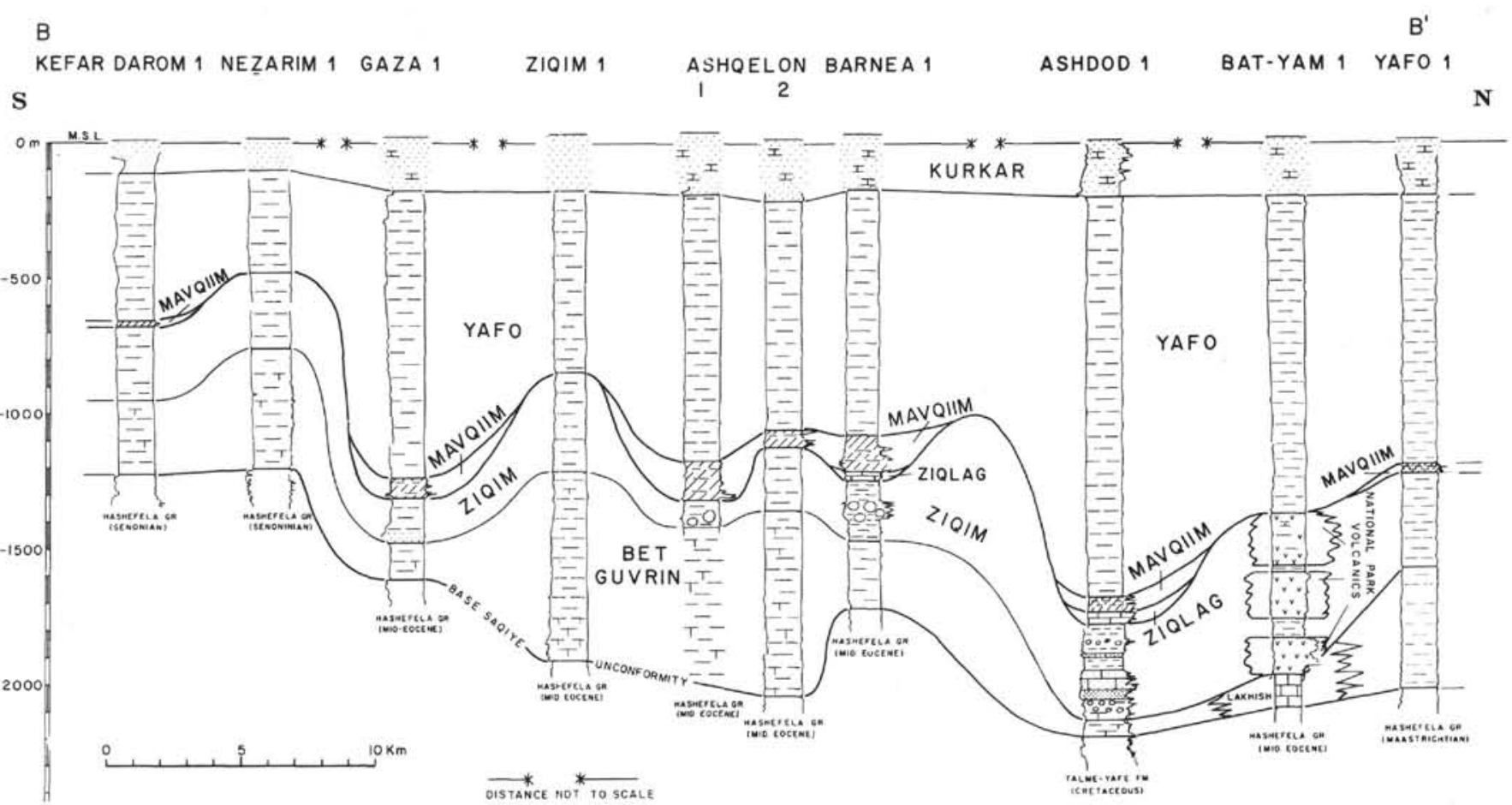

Figure 7. North-south stratigraphic cross-section B-B' along the Mediterranean coast of Israel (for location see Figure 2; for stratigraphic relationships see Figure 3; for lithology see Figure 6). The base Saqiye boundary is a regional erosional unconformity surface which separates middle Eocene or older chalks and limestones from late Eocene or younger marls and shales (Saqiye Group). The cross section cuts channels and interfluves. In the channels (boreholes Gaza 1, Ashqelon 1, Barnea 1, Ashdod 1) the Ziqim Forma tion is truncated and there is a thick fill of Ziqlag reefs and/or Mavquim evaporites. On the interfluves (boreholes Nezarim 1, Ziqim 1, Ashqelon 2) the Ziqim Formation is thicker, and the Mavquim evaporites are thinner or absent. The Yafo Formation fills the pre-existing relief. Compare with seismic record section 125-A, Figure 11.

to the west and also in the mouths of the canyons. The transgression began with the deposition of the Gaza sands and a complex of sandstones and conglomerates found in the Ashdod 1 and 2 drillholes. The stratigraphic position of the Gaza sands and the Ashdod clastics needs further clarification. Volcanic eruptions, the "National Park Volcanics," occurred simultaneously with the deposition of the Ziqim Formation. During the deposition of this cycle, the Arabian Platform as a whole was elevated and erosional and terrestrial sediments accumulated in synclinal basins. The Ziqim cycle was terminated by a regression during which the entire continental shelf was exposed and intensively incised by rivers forming channels and interfluves (Figures 11, 12, 13).

The Gaza sands and the coarse clastics of AshdodSeventeen meters of coarse- to medium-grained sand were penetrated in the Gaza 1 drillhole (Buchbinder, 1971; Kashai, 1973) between the Bet Guvrin and the Ziqim formations. The sands are probably from a nearshore environment. Buchbinder (1971) proposed that the deposition of the sands is related to the tectonic and erosional event which took place between the deposition of the Bet Guvrin and the Ziqim formations.

The sands in Gaza 1 contain Miogypsina intermedia, which according to Martinotti (1973) marks the upper part of Unit 2, and occur 30 meters below the first appearance of Orbulina. Other authors (excluding Drooger, see Martinotti, 1973) believe that the extinction of the Miogypsina group-of which the $M$. intermedia is nearly the last of the evolution lineages-occurred slightly later than the first appearance of Orbulina. According to Berggren (1972, p. 210), the Miogypsina group became extinct at the border of the Units N9/ N10 of Blow (1969), which is about 15.5 m.y.B.P. (Figure 3). In any case, the base of the Ziqim cycle is very close to the Orbulina datum.

In the Ashdod 1 and 2 boreholes, about 360 meters of the Ziqim Formation include two intercalations of sandstones and conglomerates (Figures 7 and 14 [A and B]). The Ashdod boreholes are located in a markedly large canyon. The clastic intercalations are of tidal-estuarine and fluvial environments and also indicate that a tectonic-erosional event occurred in the area.

The Ziqim Formation-(Gvirtzman and Reiss, 1965; Gvirtzman, 1970). The Ziqim Formation consists of slightly sandy, light gray shaly marls which are rich in planktonic foraminifera, and pass in places into globigerina ooze. In many drillholes, a boulder conglomerate embedded in marine marls is found in the lower part of the Ziqim Formation. The boulders are occasionally a few meters in diameter; they consist of Cretaceous limestones, dolomites, and hard chalks. Possibly this 


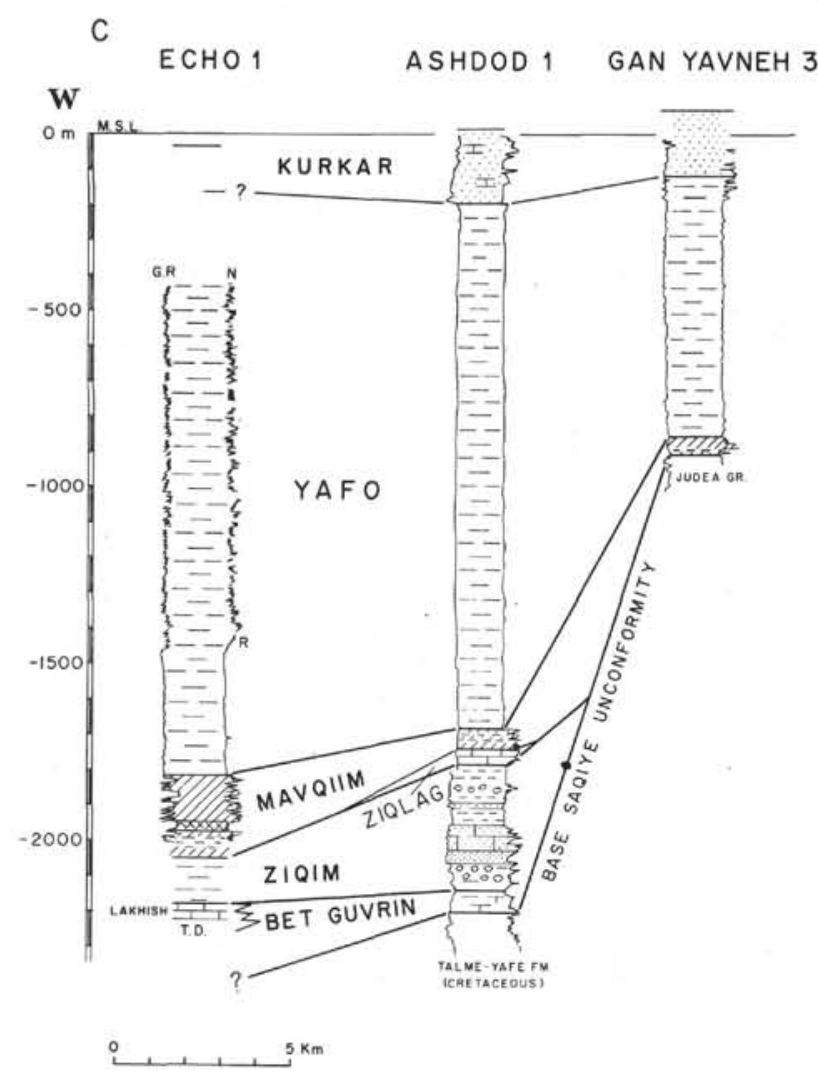

Figure 8. East-west cross-section C-C', across the platform slope (for location see Figure 2; for stratigraphic relationships see Figure 3; for lithology see Figure 6). Heavy line $=$ unconformity contact. The base Saqiye boundary is a regional erosional unconformity surface which separates middle Eocene or older chalks and limestones from late Eocene or younger marls and shales (Saqiye Group). Note the eastward wedging out of the Bet Guvrin, Ziqim, and Mavqiim formations from the Levant Basin to the platform.

boulder congolomerate formed as a huge talus creep derived from the adjacent fault scarp bordering the platform. According to Derin and Reiss (1973), the Ziqim Formation is younger than the Orbulina datum and it includes fauna of the Units $3,4 \mathrm{ml}$ and occasionally $4 \mathrm{~m} 2$. Its age is therefore Langhian, Serravallian, and Tortonian. In places, for example the Gaza 1 borehole, the base of the formation, as noted above, may be slightly below the Orbulina datum (upper Unit 2 ). In most of the coastal plain the formation overlies an erosional unconformity surface which exposes Cretaceous to middle Eocene strata as well as the Bet Guvrin Formation. In the offshore drillholes, the lower contact with the Bet Guvrin Formation is conformable. This indicates that sedimentation continued uninterrupted from the Bet Guvrin Formation into the Ziqim Formation. The upper contact is always truncated by an erosional surface showing a fluvial drainage pattern (Figures 7, 11, 12, 13). The thickness of the Ziqim Formation varies from tens of meters to 300 meters and is mainly controlled by the amount of erosion at the top. The Ziqim Formation was deposited in an open and relatively deep sea which covered the western part of the coastal plain and the offshore area.

The National Park Volcanics-(Grader and Gvirtzman, 1961). Two hundred meters of basalt and pyroclastic rocks overlie the Ziqim Formation in the National Park 1 drillhole and 468 meters of volcanic deposits occur together with two marine intercalations in the Bat Yam 1 drillhole (Figure 7). According to Derin and Reiss (1973) the marine intercalations contain fauna of Units $3,4 \mathrm{~m} 1$ and $4 \mathrm{~m} 2$; therefore, the volcanic event must have begun later than the time of the Orbulina datum and continued after the extinction of G. mayeri, i.e., from about 16 m.y. to about 12 m.y.B.P. On the basis of an aerial magnetic survey, Gvirtzman (1970) postulated that the volcanic deposits extend about $15 \mathrm{~km}$ north and south of Tel Aviv, probably where the transverse faults met with the longitudinal fault. This is indicated from several shallow boreholes east of Tel Aviv. Deposits of volcanic rocks were indeed found in the drillhole located over the magnetic anomalies. The volcanic activity in the coastal plain was approximately simultaneous with the earlier volcanic activity of the eastern Lower Galilee in northern Israel.

\section{Paleogeographic Reconstruction}

The second erosional phase on the platform and the slope (approximately 11-9 m.y.B.P)-The top Ziqim Formation is ubiquitously truncated as indicated by the seismic record sections (Figures 11, 12, 13. See also Figure 7). In the north-south seismic records, the base of the Saqiye Group is generally level whereas the surface at the top of the Ziqim Formation forms channels and interfluves. The body of the Ziqim Formation together with the underlying Bet Guvrin Formation displays more or less horizontal reflectivity. Also, the filling of the Yafo Formation above the Mavqiim reflector (see below) is horizontally bedded. The undulating plane at the top of the Ziqim Formation represents, therefore, erosional truncation. The relief at the top of the Ziqim, below the relatively thin Mavqiim anhydrite, can be easily reconstructed. To the east, where the Ziqim Formation wedges out, the relief at the top coincides with the erosional pattern of the older formations, i.e., the first erosional phase. In other words, the channels at the top of the Ziqim, which were interpreted by Gvirtzman (1969a, 1970) as a fluvial drainage system, are the result of rejuvenation of the earlier drainage system. The relief at the top of the Mavqiim anhydrite (or base of the Yafo Formation-see below) is similar to that at the top of the Ziqim Formation. Therefore Figure 17 also reflects the topography at the top of the Ziqim. This erosional topography stretches over the entire modern continental shelf of Israel. The drainage pattern (as shown in Figure 17) is believed to be of subaerial (and not submarine) origin because of its dense distributary and typical dendritic pattern. Furthermore, distributaries of the fifth and higher orders in the platform merge with distributaries of the fourth to third order on the slope, and with distributaries of the first and second order in the Levant Basin. This distributary convergence is 


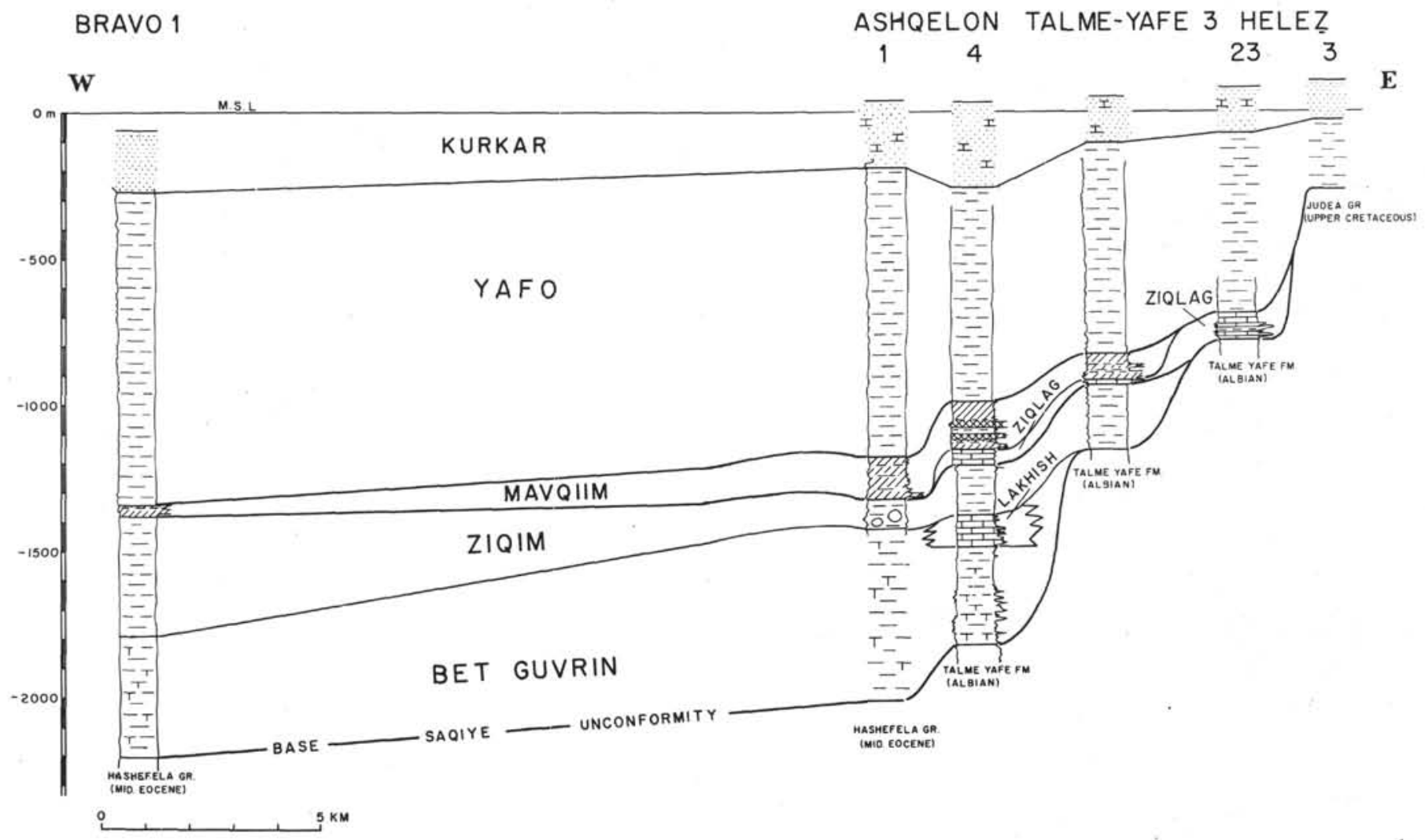

Figure 9. East-west cross-section D-D' across the platform slope (for location see Figure 2; for stratigraphic relationships see Figure 3; for lithology see Figure 6). Heavy line = unconformity contact. The base Saqiye boundary is a regional erosional unconformity surface which separates middle Eocene or older chalks and limestones from late Eocene or younger marls and shales (Saqiye Group). Note the eastward wedging out of the Bet Guvrin, Ziqim, and Mavqiim formations from the Levant Basin to the platform.

E BEERI 1 AFIQ 1 SA'AD $1^{E^{\prime}}$

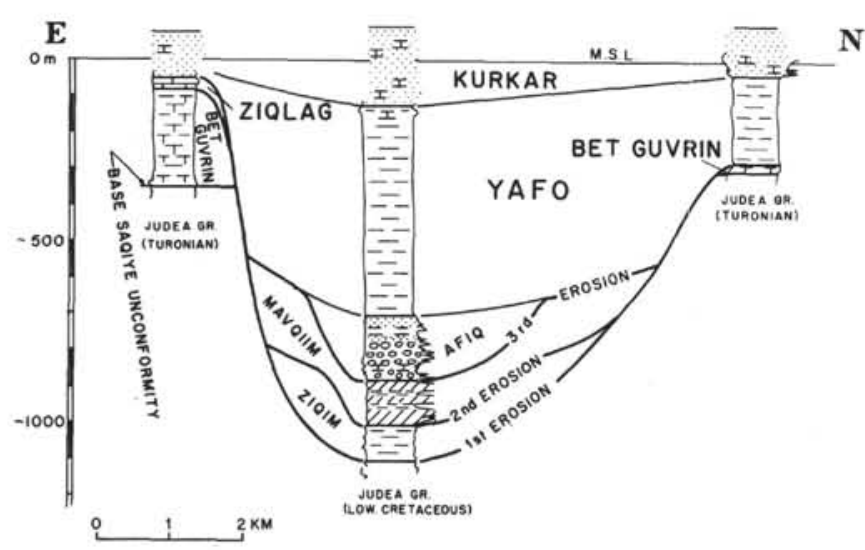

Figure 10. North-south cross-section E-E' across the GazaBeer Sheva canyon (for location see Figure 2; for lithology see Figure 6; for topography of canyon see Figures 16 and 17). Heavy line $=$ unconformity contact. For stratigraphic relationships and especially for the three erosional phases compare with Figure 3. The base Saqiye boundary is a regional erosional unconformity surface which separates middle Eocene or older chalks and limestones from late Eocene or younger marls and shales (Saqiye Group). The first erosion phase which resulted in the main incision of the canyon, post-dates the Bet Guvrin Formation and predates the Ziqim Formation. The rejuvenation of the erosion (the second erosion phase) post-dates the Ziqim Formation (see Figure 7 , cross section $\left.B-B^{\prime}\right)$. The transgression of the Ziqlag-Mavquim cycle (Figure 3) deposited the Ziqlag reef on the platform (Beeri 1 borehole) and the Mavquim evaporites in the channel. The third erosion phase incised the Mavqiim anhydrite. The Afiq conglomerate was deposited soon after, before the Pliocene transgression depositing the Yafo Formation.

typical of subaerial drainage patterns. Submarine patterns are usually more sparse, tend to diverge downslope, and are generally not dendritic.

This suggests that during the post Ziqim erosion, the entire present-day continental shelf of Israel was emerged above sea level, and that the sea remained only in the Levant Basin. Thus, in addition to the elevation differences of more than 1000 meters between the platform and sea-level after the first post Bet Guvrin tectonic uplift, the elevation differences between the platform and sea level at the end of the second uplift during post Ziqim times, gained another 1000 meters totaling about 2000 meters. 


\section{The Ziqlag-Mavqiim Sedimentary Cycle (Tortonian- Messinian)}

\section{Stratigraphy}

General-The Ziqlag Formation represents a transgression over the truncated relief and the Mavqiim Formation represents the following regression which corresponds to the Messinian desiccation event which occurred throughout the Mediterranean. The Afiq and Bet $\mathrm{Nir}$ conglomerates represent the regressive fluvial phase at the end of the sedimentary cycle.

The Ziqlag Formation-(Gvirtzman and Buchbinder, in Gvirtzman and Reiss, 1965). The Ziqlag Formation consists of biocalcarenites and coral reefs; it is occasionally dolomitized. Indicative fossils include Borelis melo and mollusk assemblages similar to the Miocene assemblages of the Vienna Basin (Rothmann, 1967). On the basis of the paleontological evidence only, it appears that the Ziqlag Formation post-dates the Orbulina datum. However, the lithostratigraphic position of the formation between the Ziqim and Mavqiim formations (see discussion below) indicates a Tortonian age (Figure 3 ).

The Ziqlag Formation overlies a truncated surface lying above the Ziqim Formation and older formations of Cretaceous and Tertiary age. It is overlain by the Mavqiim anhydrite, the Yafo Formation, the Bet Nir Conglomerate, and other younger formations. Its thickness varies from a few meters to approximately 300 meters. Buchbinder (1975a) distinguished two main facies groups in the Ziqlag Formation: (1) biocalcarenite of shallow marine and beach origin on the platform; and (2) coral reefs deposited as fringes following the transgressive shoreline on the platform edge, on the slope and in the erosional canyons (Figure $14[\mathrm{C}-\mathrm{I}]$ ). The fore-reef zone is characterized by skeletal debris and algal rhodoliths interbedded with marls (Figure 14 $[\mathrm{F}, \mathrm{H}, \mathrm{I}])$. The reefal bodies on the slope occur in irregular patches, especially around the erosional canyons, and do not form a continuous sheet. The platformbiocalcarenites, however, probably formed a continuous veneer over the foothills area. Buchbinder (1975a) also reported a marly tongue within the reef limestones at the platform edge.

The erosional relief at the base of the Ziqlag Formation is at 2290 meters below sea level in the Joshua 2 borehole (Figure 6) and at 518 meters above sea level in the outcrops of the foothills area, on the platform. Part of this difference in elevation can be attributed to younger Pliocene-Pleistocene westward tilting (Neev, et al., 1976). However, the present-day slope is the result of an original drainage slope and the additional westward tilting in Pliocene-Pleistocene times. The effect of this younger tilting may be discounted: readjustment of the westward tilt to the maximum extent possible in order to retain the westward drainage pattern gives a minimum elevation difference of about 2000 meters along the Ziqlag unconformity plane.

The Mavqiim Formation-(Gvirtzman, 1970). The formation consists of anhydrite, gypsum, rock salt, and dark marly shales. The interbedded marls in the
Mavqiim evaporites contain a few planktonic foraminifera which were assigned to Unit $4 \mathrm{~m} 2$ (Derin and Reiss, 1973), and thus indicate a Tortonian-Messinian age. However, since the Mavqiim Formation corresponds to the " $M$ "' horizon which is known to represent the Messinian desiccation event throughout the entire Mediterranean area, a Messinian age is implied (see discussion below).

The Mavqiim Formation overlies the Ziqlag Formation. It unconformably overlies Cretaceous to Tertiary formations and the Miocene Ziqim Formation and it is overlain by the Afiq Formation and the Yafo Formation. Its thickness varies from a few meters to over 200 meters.

The internal sedimentary structures of the Mavqiim Formation include nodular anhydrite, mostly of the chicken-wire variety (Figure 15[G]). Occasionally, distorted, enterolithic, and flattened nodules are found (Figure 15[A, B, C, D, F]). Banded nodular anhydrites with undulating layers of interlayered dark organic matter, resembling algal stromatolites and algal mats, are also common (Figure 15[B, D, E]). As generally accepted in the literature (Shearman, 1966), these types are attributed to a sabkha environment. Similarly, the Messinian anhydrites drilled by the Deep Sea Drilling Project in the central Mediterranean basins were attributed mainly to sabkha environments (Ryan, Hsü et al., 1973; Friedman, 1973). Laminated anhydrite showing a possible small-scale cross stratification (Figure 15[I]) was found in the Ashdod 2 well within a nodular anhydrite sequence. It probably represents subaqueous clastic deposition in shallow lagoons. Rock salt deposits, several tens of meters thick, were detected within the anhydrite sequence in the Ashqelon 4 (Figure 5), Joshua 2 and Echo 1 (Figure 6) boreholes, all located in erosional channels. It therefore appears that the salt was restricted to low-lying areas occupied by salt ponds, while anhydrite sabkha deposition prevailed on the elevated peripheries. The marly marine intercalations within the evaporites also contain benthonic foraminifera with dwarfed, stunted forms, which indicates a depletion zone (Perath, 1965). The number of marine intercalations within the evaporite sequence is not constant and varies from zero to seven.

The Mavqiim evaporites are mostly restricted to the slope and basin areas. In one instance, however, the evaporites were also found on the platform edge. This was in the Beeri SH-4 borehole on the southern shoulder of the Gaza-Beer Sheva channel (Figure 10, near the Beeri 1 borehole). This occurrence was previously considered by Gvirtzman (1970) as an intercalation within the Yafo Formation, but it now appears that the Beeri gypsum belongs to the Mavqiim Formation as suggested by Derin and Reiss (1973). The Mavqiim evaporites form a characteristic continuous veneer which plaster the erosional surface at the top of the Ziqim Formation-both over the canyon beds and the interfluves. In the canyons the thick sequence of evaporites is covered by the sandstones and the conglomerates of the Afiq Formation. The evaporite sequence is occasionally accompanied by the Ziqlag coral reefs at its base and by coarse clastics at its top, and forms a 

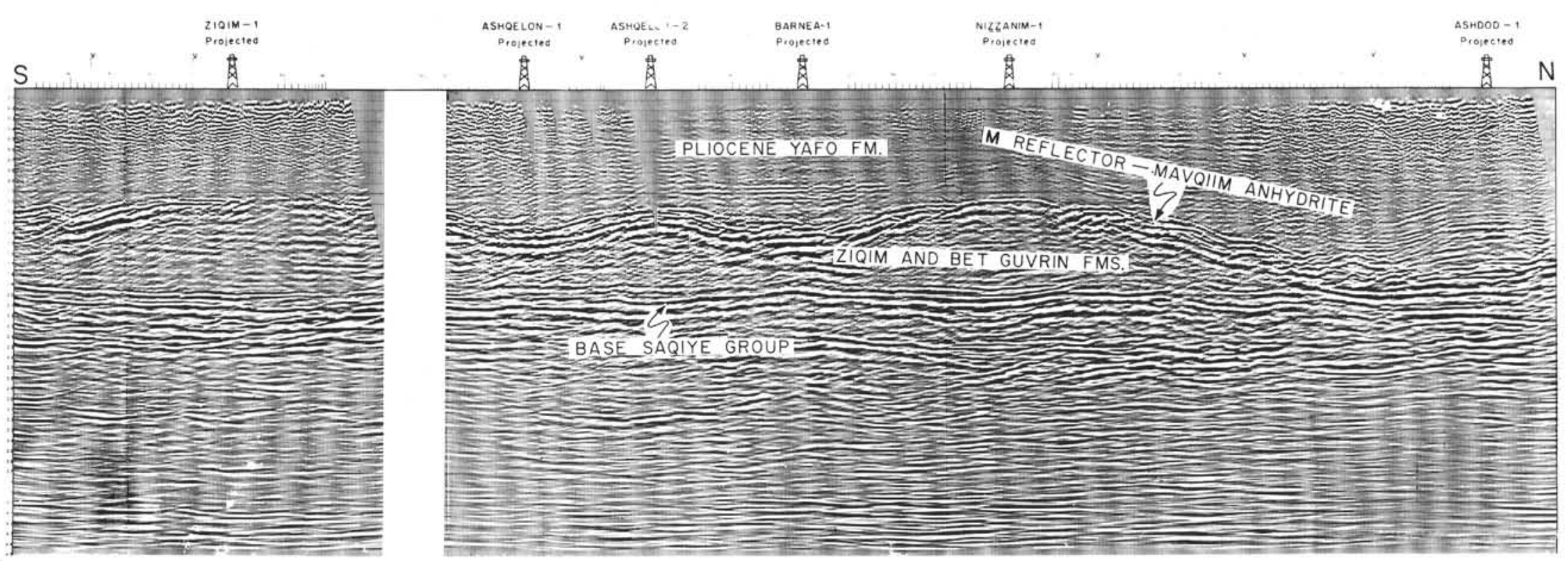

Figure 11. Onshore seismic record section 125-A along the Mediterranean coastline (for location see Figure 2). Note the flat base of the Saqiye Group (an unconformity surface), the high reflectivity of the mostly horizontal beds of the Ziqim and Bet Guvrin formations, and the undulating reflections of the Mavqiim anhydrite overlying the truncated top of the Ziqim Formation. This section runs perpendicular to the erosion channels: boreholes A shdod 1, Barnea 1, and Ashqelon 1 are located in the channels and Nizzanim 1, Ashqelon 2, and Ziqim 1 are situated on the interfluves. Compare with Figure 7 (cross-section B-B'), Figure 16 (contour map on the Mavqüm anhydrite) and Figure 17 (reconstruction of the drainage systems).

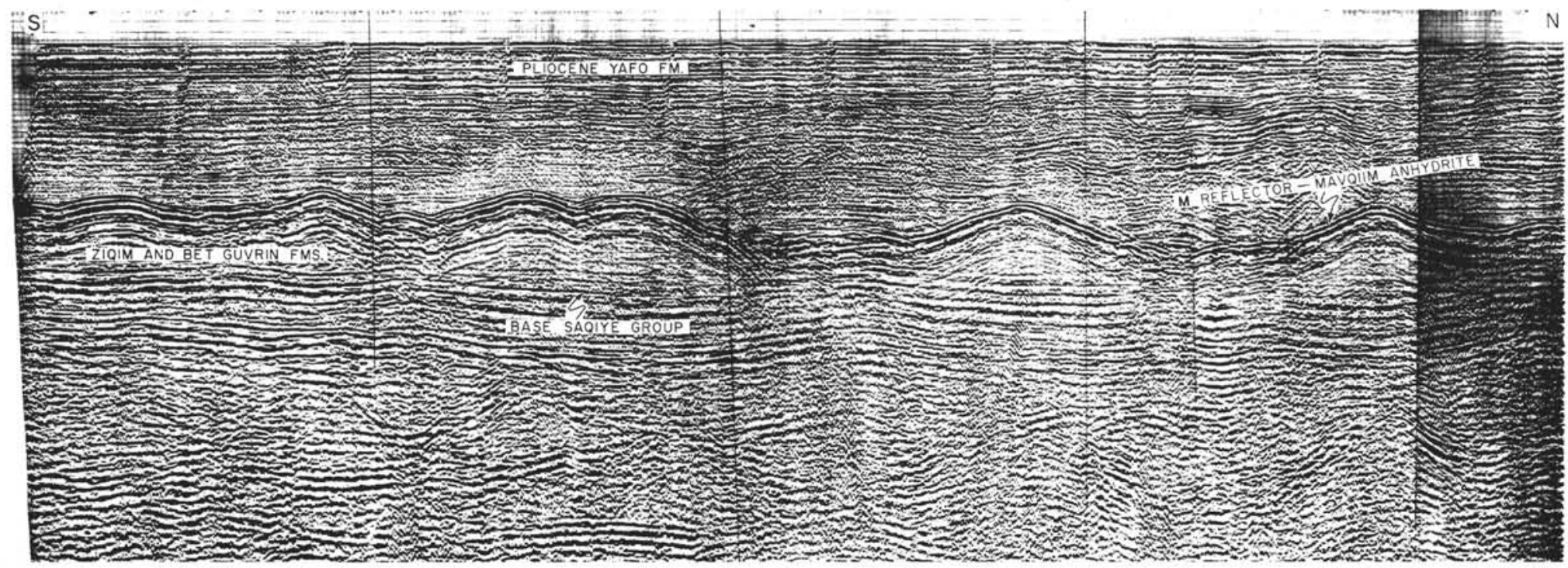

Figure 12. Offshore seismic record section 44, parallel to the Mediterranean coastline (for location see Figure 2). The same features observed in Figure 11 can be observed in this profile which also runs perpendicular to the erosion channels. Note that the Ziqim Formation is almost entirely eroded along the channel thalwegs. Also note the high reflectivity of the Yafo Formation which fills the pre-existing relief and exhibits almost horizontal bedding. 
highly distinctive seismic reflector separating the Ziqim Formation from the Yafo Formation (Figures 11, 12, 13).

The Afiq Formation and the Bet Nir Conglomerate-The Afiq Formation (Gvirtzman, 1970) consists of conglomerates, variegated shales, sandstones, siltstones, and marls. The conglomerates are composed of Cretaceous and Tertiary pebbles from the exposed mountain formation. In previous studies, the Afiq Formation was assigned as a member of the Mavquim Formation (Gvirtzman, 1970), but we considered it separately in this study. The Afiq Formation rests on the Mavqiim Formation, and is overlain by the Yafo Formation. It is restricted to the canyon thalwegs and was deposited in fluvial and lacustrine-marsh environments in river channels and flood plains. In the Afiq 1 borehole (Figure 10) a sandstone (Figure $15[\mathrm{~K}]$ ) and a conglomerate-probably a lag deposit at the base of a channel-were found in a core sample overlain by sandstone with slight trough cross-bedding (Figure 15 [J]). Fresh water ostracodes were found in a variegated shale facies in the Mavqiim 2 borehole (E. Gerry, 1964, The Israel Petroleum Institute, unpublished written communication).

The Bet Nir Conglomerate (Gvirtzman and Buchbinder, 1969) is known from outcrops in the coastal plain and Hashefela (foothills) area. It consists of unsorted pebbles of limestone, chalk, and grit of Cretaceous to Tertiary age, and of pebbles derived from the Ziqlag Formation. The matrix is mostly weathered to caliche. The Bet Nir Conglomerate overlies chalks and marls of Tertiary age as well as the Bet Guvrin, Lakhish, and Ziqlag formations. It is covered by soils and other younger sediments. The conglomerate outcrops exhibit a distinct fluvial drainage pattern. In previous studies the Bet Nir Conglomerate was assigned to the Yafo cycle together with the Ziqlag Formation. Following the considerations mentioned above, we now believe that the Bet Nir Conglomerate is the surface extension of the Afiq Formation, which is known only from drillholes. Both formations appear to represent continuous fluvial deposition which terminated the Ziqlag-Mavqiim sedimentary cycle.

\section{Paleogeographic Reconstruction}

Transgression of the Ziqlag reef over the platform (approximately 9-7 m.y.B.P.)-In previous works the Ziqlag Formation was regarded as part of the Yafo sedimentary cycle (Reiss and Gvirtzman, 1966b; Gvirtzman and Buchbinder, 1969; Gvirtzman, 1969a, 1970), because the contact between the Ziqlag and Mavqiim had not as yet been penetrated by any well. However, the Ziqlag Formation was later found to underlie the Mavqiim anhydrite in boreholes drilled in the western coastal plain and the offshore area. Derin and Reiss (1973) therefore proposed that the Ziqlag Formation was a time equivalent of the Ziqim Formation. However, since the top of the Ziqim Formation is truncated and the Ziqlag Formation rests on this erosional surface, we contend that the two formations represent separate sedimentary cycles, wherein the

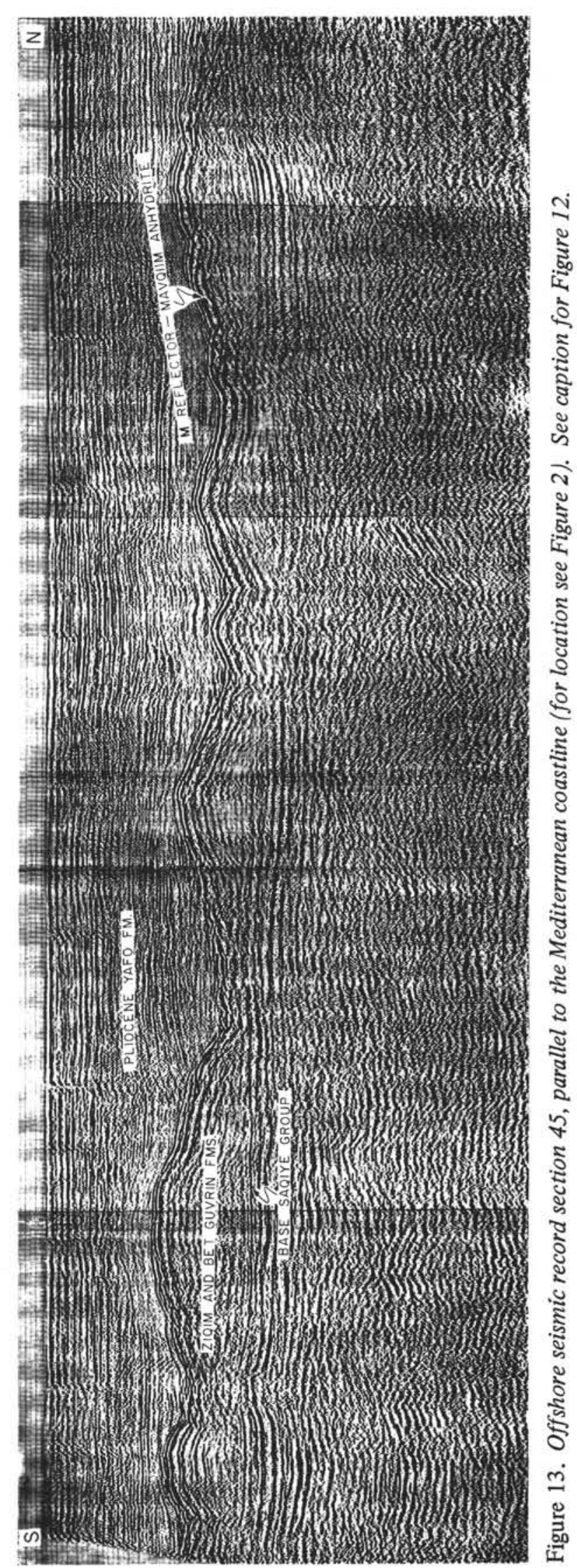



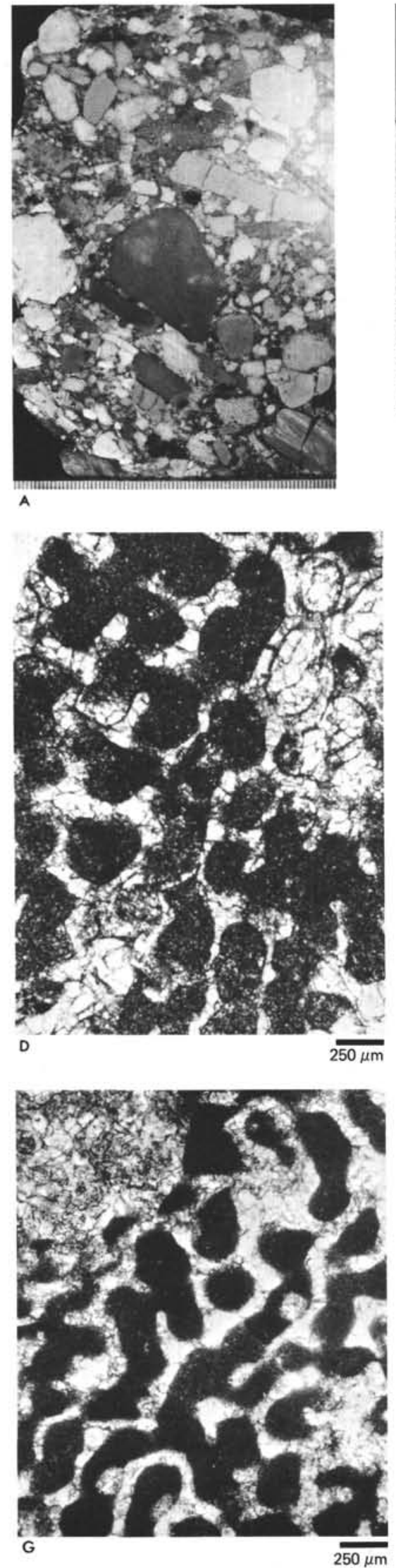

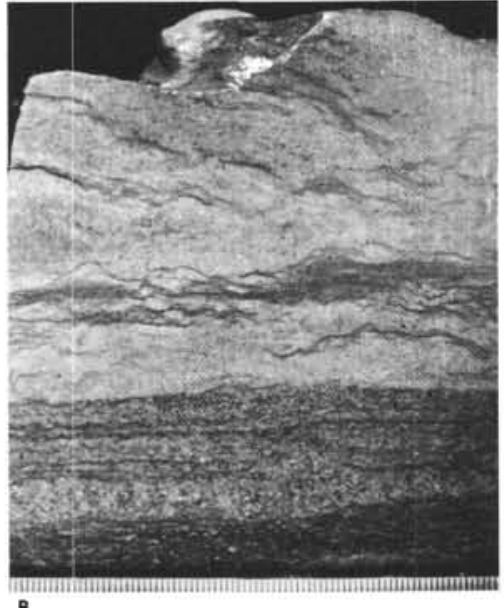

B
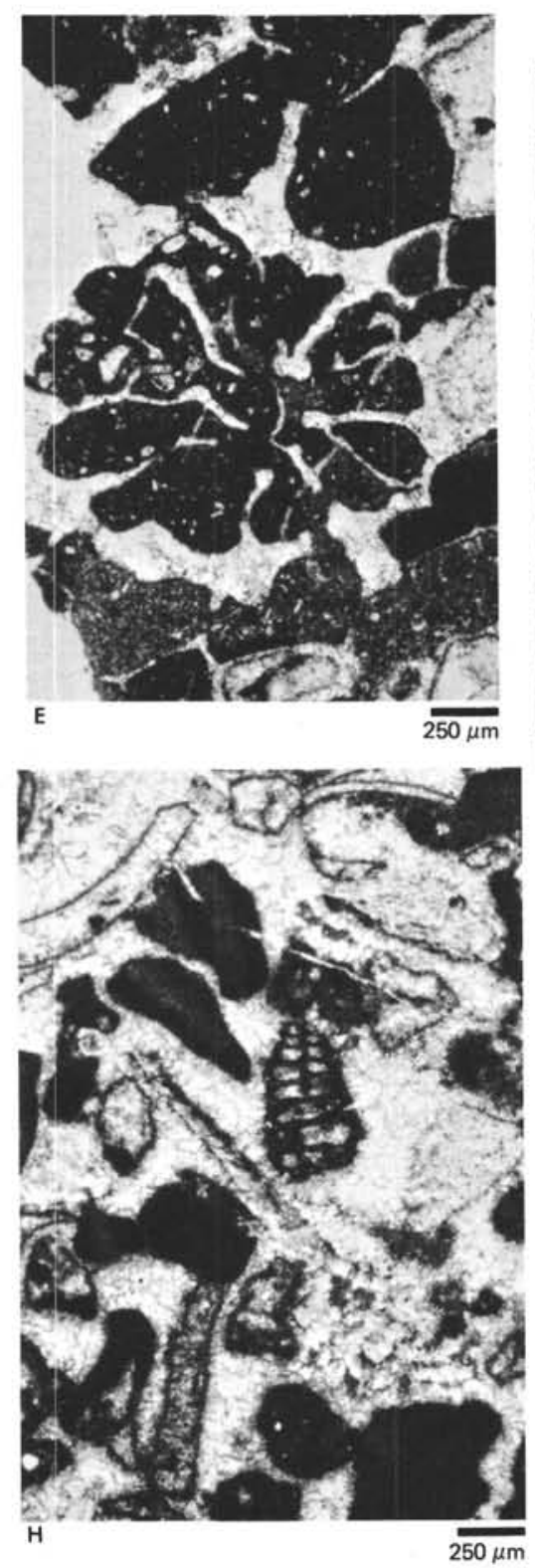

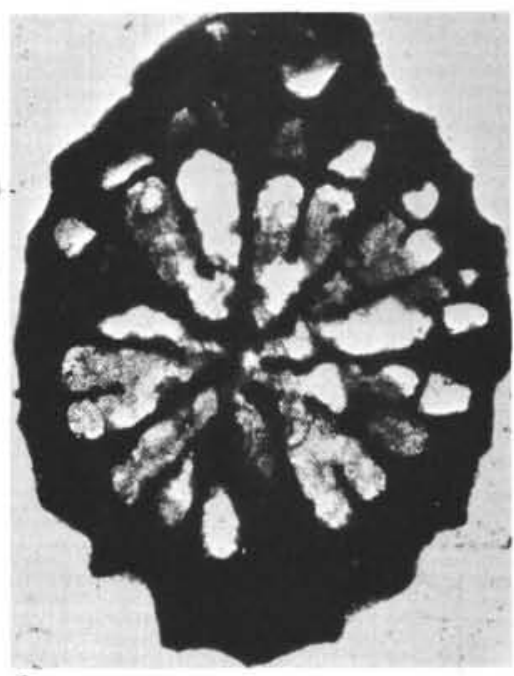

C

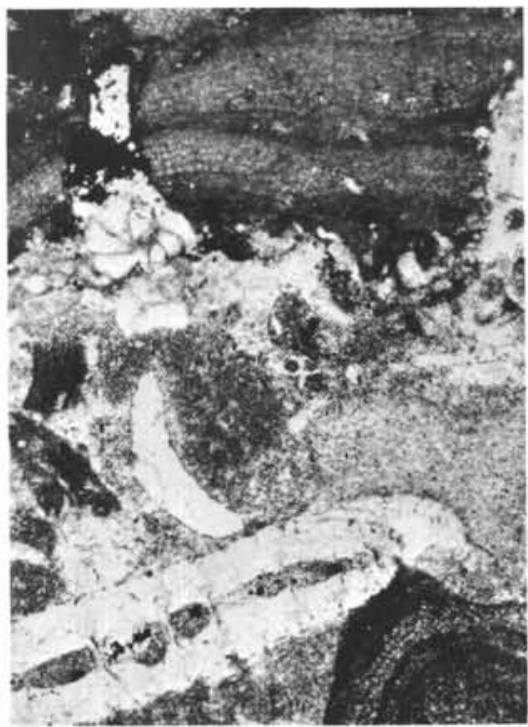

$250 \mu \mathrm{m}$

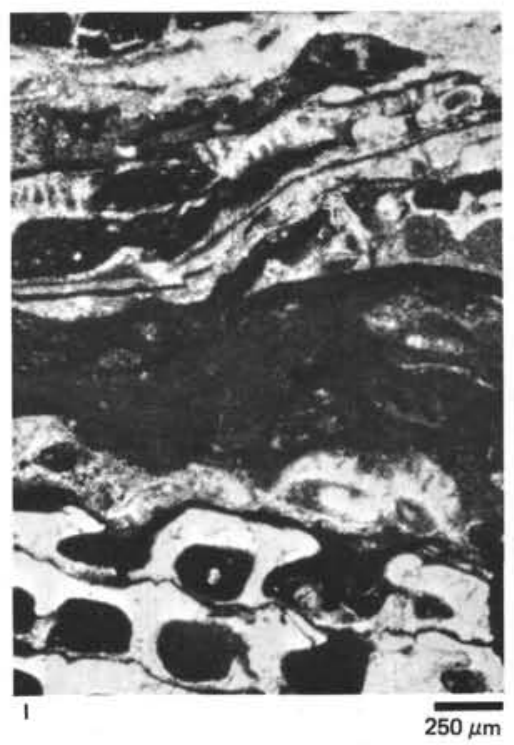

Figure 14. $(A, B)$ Polished core slabs of the coarse clastics from the Ashdod 2 borehole (Core 2, $1892-1906 \mathrm{~m}$, scaleunits in $\mathrm{mm}$ ): (A) Conglomerate consisting of pebbles of Cretaceous to Tertiary limestones and chalks. (B) 


\begin{abstract}
Medium-grained calcareous sandstone, showing horizontal and wavy laminations (flaser bedding?), probably of tidal origin. (C-I) Photomicrographs of thin sections fromthe Ziqlag Formation, from drillholes in the coastal plain and containental shelf of Israel: (C) A faviid corallite, Joshua 2, 2265 meters. (D) A portiid coral, Joshua 2, 2290 meters. (E) A colony of faviid corals, Barnea 1, 1275 meters. (F) Coralline algae crusts interbedded with foraminiferal biomicrite, Helez 23, 780 meters. (G) A poritiid coral, Ashqelon 4, 1220 meters. (H) Skeletal biosparite; debris includes foraminifera, pelecypods, and coralline algae (dark), Mivtah 1, 1160 meters (near Gan Yavne 3 borehole). (I) Alternating crusts of coralline algae and encrusting foraminifera, Mivtah 1, 1090 meters.
\end{abstract}

Ziqlag Formation represents a new transgression over a truncated surface and the Mavqiim anhydrite and its overlying conglomerates represent the regression.

Both the Ziqlag Formation and the Mavqiim evaporites represent continuous sedimentary events of great areal distribution. The Ziqlag Formation was found over the entire slope from the Joshua 2 well (on the slope) to the outcrops along the foothills area. It was deposited on a sloping relief with an original elevation difference of over 2000 meters. The Mavqiim anhydrite occurs from the platform edge through the slope and into the Levant Basin.

The combining of the Ziqlag-Mavqiim formations into a separate sedimentary cycle, however, poses some difficulties. According to this interpretation, when the Ziqlag sea reached the platform relatively deep water should have prevailed in the slope area depositing open sea marls over the reefs. However, there is no clear indication that a marly sequence exists between the reef and anhydrites in the slope area. Buchbinder (1975a) reported a marly sequence in the Ziqlag reefs at the platform edge which may represent a general deepening in the slope area when the transgression reached the platform. However, these marls could also be the result of local oscillations in the sea level. The absence of unequivocal deep water sediments could be related to erosion and winnowing by waves during the following regression which left only the cemented reefal sediments behind.

The time of the beginning of the Ziqlag-Mavqiim cycle is not clearly known. The Ziqlag transgression is assigned to the biostratigraphic unit $4 \mathrm{~m} 2$ which represents a relatively long period of time. The time period, 11-9 m.y.B.P., given for the second erosion phase (Figure 3) between the Ziqim and Ziqlag formations is very tentative. We presume, however, that both the Ziqlag transgression and the Mavqiim regression occurred fairly quickly and that each lasted about two million years.

The Messinian desiccation event, the third erosional phase and its drainage system (approximately 7-5 m.y.B.P.) - The Mavqiim evaporites were deposited along sabkha belts which moved westwards following the regressive shoreline. The sabkhas started to develop from the platform edge. In this respect, the topographic contours represent isochronic lines of deposition. The position of the evaporites at the Beeri SH-4 well on the shoulders of the Gaza-Beer Sheva canyon versus the position of the evaporites at the canyon bottom (Afiq 1 borehole) is noteworthy (Figure 10). Obviously the anhydrite in the two wells is diachronous and the Mavqiim Formation in the bottom of the channel is younger. Further retreat of the shoreline resulted in the accumulation of fluvial clastic sediments covering the evaporites, probably in rejuvenated channels. Gvirtzman (1969a, 1970) suggested that the top of the Mavqiim Formation represents a drainage system which probably continues in the Levant Basin as far as Cyprus. Later-following the discovery of the Messinian evaporites in the deep Mediterranean basins during Leg 13 of the Deep Sea Drilling Project, and after the correlation between the evaporites and the M-reflector was suggested by Hsü et al. (1973)-Neev et al. (1973, 1976), Derin and Reiss (1973), Buchbinder (1975a), and Ginzburg et al. (1975) proposed that the Mavqiim Formation is the extension of the Messinian evaporites.

We postulate that the drainage systems which are shown in Figure 17 (derived from contour map, Figure 16) drained into the basins that existed during the Messinian in the eastern Mediterranean.

\section{The Yafo-Kurkar Sedimentary Cycle (Pliocene- Pleistocene)}

\section{Stratigraphy}

General-This cycle includes the Yafo Formation, which represents the Pliocene transgression, and the Pleshet Formation (the lower part of the Kurkar Group), which represents the regression. The sediments of the upper part of the Kurkar Group represent the eustatic oscillations during the Pleistocene. The sediments of this cycle are the first to invade the Dead Sea rift (through the Emeq Valley transversal rift between the Galilee and the Shomeron) (Figure 18), and tie the marine sedimentation in the west with the continental sedimentation in the east.

The Yafo Formation-(Gvirtzman and Reiss, 1965). The Yafo Formation consists of homogeneous gray clayey marl. Thin shell beds and sandstone layers occur in its upper part. The age is designated Pliocene to early Pleistocene on the basis of planktonic foraminifera (Derin and Reiss, 1973) and on mollusks (Moshkowitz, 1963). The base of the Yafo Formation marks the first appearance of $G$. margaritae, and the entire sequence includes the units $4 \mathrm{p} 1,4 \mathrm{p} 2,5$ (Derin and Reiss, 1973). The top of the formation is diachronic and to the west it contains the first appearance of G. truncatulinoides (Figure 3).

The Yafo Formation rests on an erosional topography. In the western coastal plain and offshore it overlies the Ziqim, Mavqiim, and Afiq formations. On the platform, or in places where the Mavqiim Formation is missing, it overlies limestones and chalks of 

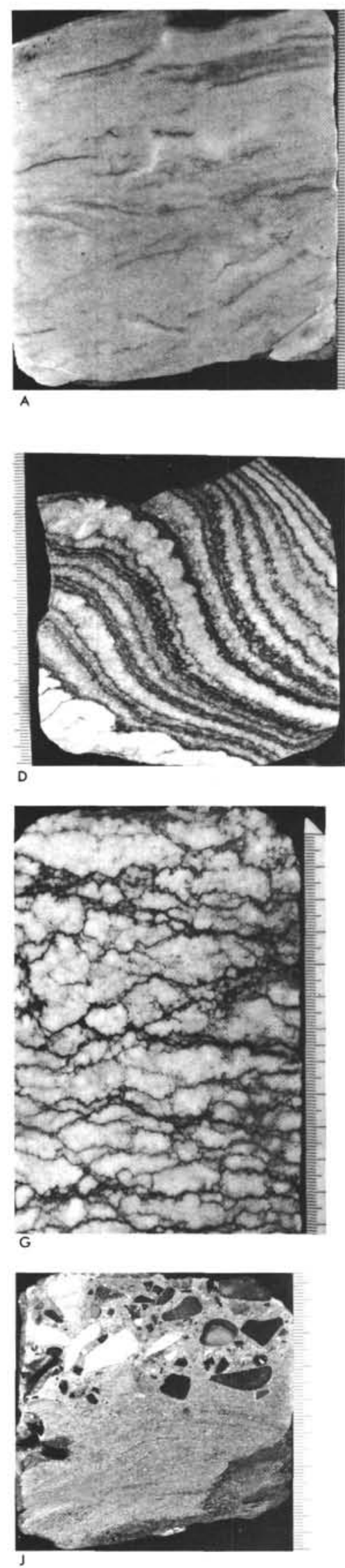
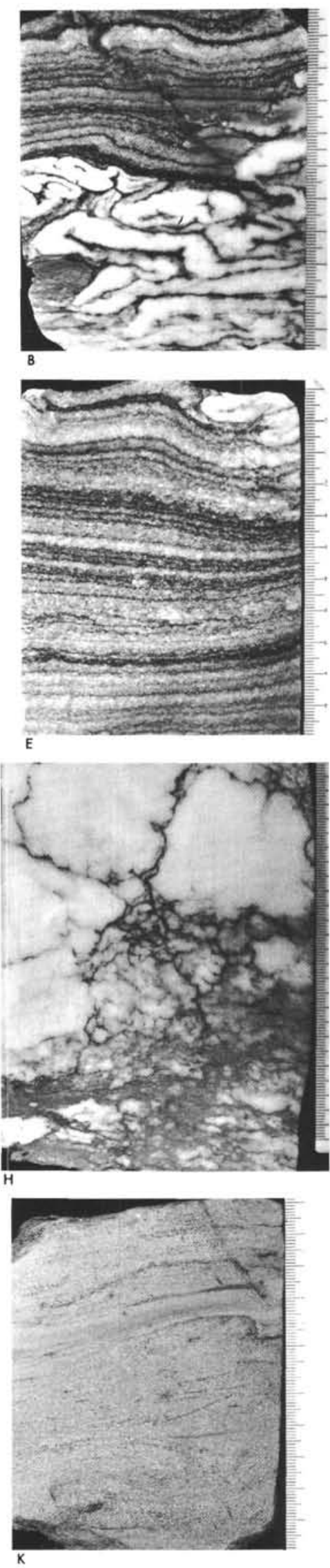
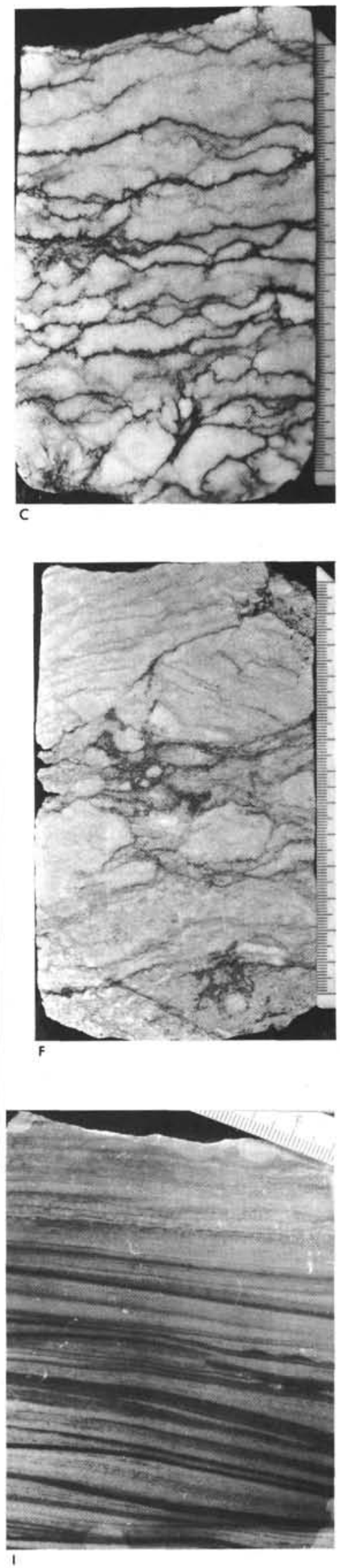

Figure 15. Polished core slabs of the Mavquim anhydrite (A-I) and from the Afiq Formation (J-K). Metric scale. (A-G) Samples taken from the Yafo 1 borehole (core 7, 1216-1221.5 meters, samples 
$2,3,9,12,17,25$, and 27 from top to bottom, respectively). (H) sample from the Talme Yafe 3 borehole (Core 2, 918.0-921.7 meters). (I) Sample from the Ashdod 2 borehole (Core 1, 1595-1606 meters).(J-K)Samples from the Afiq Formation at the Afiq 1 borehole (Core 7, 805.3-811.7 meters). (A)Displaced laminae of nodular anhydrite. Nodules are 1-2 $\mathrm{mm}$ across. The dark laminae are brownish anhydrite rich in organic matter. The distortion of the laminae is probably related to desiccation. (B) The lower light part is composed of highly contorted enterolithic anhydrite. The overlying part is composed of dark banded nodular anhydrite alternating with dark, fine, organicrich matter laminae, probably algal mats. Note the oblique crack filled with clear anhydrite which probably originated as a desiccation crack. Post-depositional deformation (compression) of both units is indicated by the contortion and overthrusting structures. (C) Bedded nodular anhydrite showing flattening and stylolitic truncation of both the upper and lower surfaces, presumably due to processes of solution and precipitation. (D) Wavy, banded enterolithic anhydrite composed of alternating laminae of light enterolithic anhydrite with dark, organic-rich matter, fine nodular anhydrite, characteristic of algal stromatolites. (E) Banded nodular anhydrite representing algal mats, composed of alternating laminae of light nodular anhydrite with dark organic-rich matter, fine laminae of nodular anhydrite. (F) Disrupted beds of flattened modular anhydrite. Note the stylolites and solution cavities. (G)Chicken-wire anhydrite showing flattening and stylolitic boundaries. $(H)$ Large anhydrite nodules with stylolitic boundaries that overlie argillaceous laminae encasing small anhydrite nodules. (I) Laminar anhydrite showing possible small-scale cross-stratification probably represents subaqueous clastic deposition in a shallow lagoon. (J) Flint (Senonian and Eocene) and limestone (Upper Cretaceous) pebble conglomerate - probably a lag deposit at the base of a channel, overlain by medium-grained sandstone with slight trough cross-stratification. (K) Cross stratified sandstone. Note the interbedded silty layer.

Cretaceous to Tertiary age and the Bet Guvrin, Lakhish, Ziqim, and Ziqlag formations, and the National Park volcanics, respectively. The Yafo Formation is overlain by younger strata of the Kurkar Group or by soil. The Yafo sediments fill and level the relief on top of the Mavqiim anhydrite. They vary in thickness from a few meters in the eastern coastal plain to 2000 meters in the offshore area (Joshua 2 borehole, Figure 6). The Yafo Formation is rich in planktonic and benthonic foraminifera; however, the planktonbenthonic ratio decreases toward its upper part which indicates a shallowing sea. The nature of the benthonic assemblages also suggests a shallowing sea (Perath, 1965).

The dominance of montmorillonite over kaolinite and illite in the clay mineral assemblage of the Yafo Formation, in contrast to the dominance of illitickaolinitic clays over montmorillonite in the Lower Saqiye marls, attests to higher sediment contribution from the Nile River (Gvirtzman, 1970). The montmorillonite-rich clay sediments, according to this interpretation, were transported in suspension by an offshore current which moved westward, parallel to the shores of the eastern Mediterranean. Nachmias (1969) also found that the heavy mineral suite in the Yafo Formation compounded the assemblage of the lower Saqiye indicates an increased influence of the Nile River. The Yafo Formation contains amphibole-epidote-kyanite assemblages derived from the African volcanic terrains, in addition to the normal "Nubian suite" which includes mainly zircon-rutile-tourmaline and characterizes the Lower Saqiye.

The Kurkar Group-The Kurkar Group contains various rock units whose relationships are not completely known. It consists of marine sandstones of nearshore environments, indurated eolianites, fossil sandy loams, swamp mud, alluvial, and colluvial de- posits. This group is characterized by a notable and sharp transition from the argillaceous sediments of the Saqiye Group into coarse clastics, especially sandstones. Age-indicative fossils are missing. However, the most eastern outcrops of the Kurkar Group, the Pleshet Formation (Issar, 1961; Gvirtzman and Buchbinder, 1969; Gvirtzman, 1970), were assigned a Pliocene to early Pleistocene age and probably represent the nearshore sandstones of the Yafo open-sea marls. The upper units of the Kurkar Group contain human artifacts and the sediments reflect the eustatic oscillations of the upper Pleistocene. The sandstone suite of the Kurkar Group is still accumulating today on the shallow continental shelf, whereas marly clay deposits characterize the deeper shelf, continuing the deposition of a facies similar to the Saqiye Group.

\section{Paleogeographic Reconstruction}

The new Pliocene regime (after 5 m.y.B.P.)-The new Pliocene regime is characterized by several major changes in the Mediterranean and in the Middle East region. These changes include a new shoreline configuration, changes in temperature and faunal assemblages, and the extensive development of the submarine Nile cone. The maximum extent of the Pliocene shorelines is reconstructed in Figure 18.

The reflooding of the Mediterranean by oceanic waters through the Gibraltar Gate, after the prolonged desiccation, marks the beginning of the Pliocene and, in Israel, the beginning of the Yafo transgression. Thousands of meters of marly sediments accumulated in the western coastal plain and the continental shelf of Israel during this cycle which practically leveled the pre-existing erosional relief and masked the elevation differences between the platform and the slope. The thick Yafo sediments accumulated in the form of a longitudinal prism, and a new shelf-break developed 


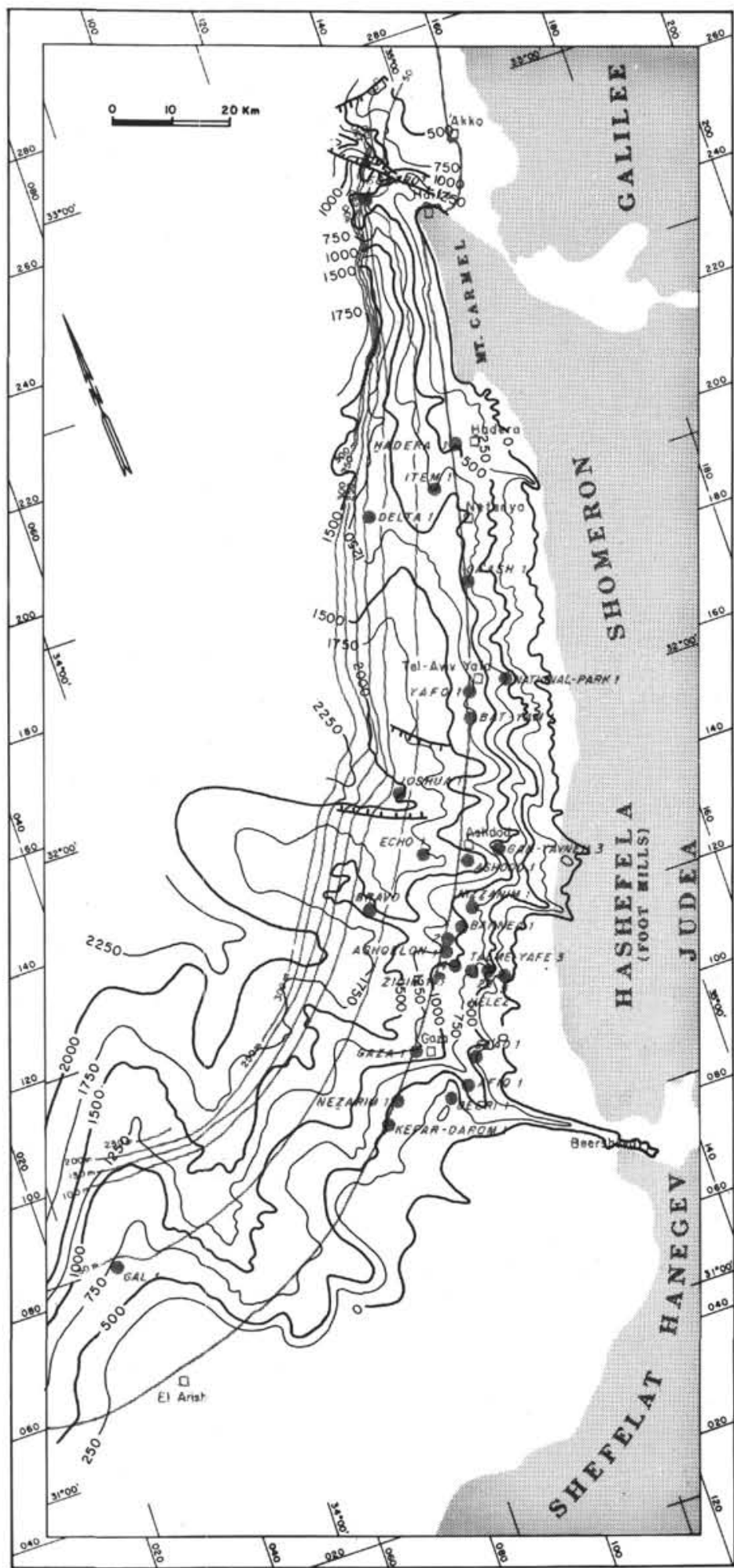

Figure 16. Contour map of the unconformity surface at the base of the Yafo Formation (Pliocene). The contour interval is 250 meters. In most of the contoured area the Yafo Formation overlies the Mavquim anhydrite. The Mavquim anhydrite is absent from both the eastern part of the contoured area (particularly to the east of the $500 \mathrm{~m}$ contour) and the northern part (boreholes Delta 1, Item 1, Foxtrot 1, Hadera 1 and 
Ga'ash 1). The contours show the relief of the Messinian erosional surface, during which the mapped area was exposed. The drainage pattern expressed by this relief is portrayed in Figure 17. Sources: Offshore - Petrocana, 1965; Gvirtzman, 1969a, 1970; Ginzburg, 1971; Neev et al., 1973, 1976; Ginzburg et al, 1975. Onshore - Gvirtzman, 1969a, 1970; Greenfield and Bino, 1974; Buchbinder, 1975a.

tens of kilometers west of the old one. The tropical Miocene fauna (foraminifera, mollusks, and hermatypic corals) was replaced by cooler Pliocene assemblages (Moshkowitz, 1968; Cita, 1973) with the notable absence of coral reefs (Chevalier, 1961; Buchbinder, 1975b).

The Pliocene transgression, which again reached the level of the Arabian Platform, entered the Gaza-Beer Sheva canyon and reached a few kilometers east of Beer Sheva (Gvirtzman and Buchbinder, 1969). The new transgression penetrated the Dead Sea rift valley through the Emeq Valley; simultaneously, the Red Sea was opened to the Indian Ocean through the Bab el Mandeb Strait. It is probable that the Pliocene transgression also reached the Gulf of Elat near Nueiba. However, it is not yet clear whether there was a continuous connection between the Mediterranean and the Red Sea through the Rift Valley. The absence of marine sediments of post-Miocene age in the Gulf of Suez probably indicates that the Gulf was emerged above sea level during the Pliocene. The Pliocene penetration through the Nile Valley reached as far as $1200 \mathrm{~km}$ inland (Chumakov, 1967, 1973). Despite this deep penetration, the River Nile discharged a huge volume of fine-grained erosional products into the eastern Mediterranean, including the silts and clays of the Yafo Formation.

The extensive construction of the Nile Delta cone on the floor of the Mediterranean occurred after the Messinian event. Said $(1973,1975)$ reported 2000 to 4000 meters of fine-grained clastic Pliocene sediments above the Messinian evaporites in the northern downfaulted block of the Delta (onshore boreholes: El Tabia, Buseili, and Kafr el Sheikh; offshore boreholes: Rosetta, Abu Qir, and Baltim). We believe that the stromatolites which he reported from the Sidi Salem borehole (Said, 1973) are probably equivalent to the Messinian evaporites. The 1300-meter sequence of conglomerates found overlying the anhydrite in the Kafr-el-Sheikh borehole (Said, 1973) appears to correlate to the Afiq Formation, since they are located in the canyon thalweg of the ancient Nile down to 4048 meters below the present sea level.

The argillaceous suite of the Yafo sediments was replaced by a sandstone suite during the Pleistocene. The penetration of the Pliocene transgression into the Nile Valley probably prevented the supply of coarse clastics to the Mediterranean during the Pliocene and consequently marly sedimentation prevailed. However, when the sea left the Nile Valley in the Pleistocene, Nile sands were once again transported to the Mediter- ranean and carried by longshore currents to the coast of Israel.

\section{IMPLICATIONS OF THE MESSINIAN EVENTS THROUGHOUT THE ENTIRE MEDITERRANEAN}

\section{Deep Desiccation Versus Shallow Desiccation Model}

The debate on this issue is well documented in the Initial Reports of the Deep Sea Drilling Project, Volume 13 (Ryan, Hsü et al., 1973) and in the many studies of a wide geological and geophysical spectrum that were presented at a symposium on the Messinian events held at Utrecht (Drooger, 1973a). We will not summarize here the arguments of the advocates of the shallow basin model (e.g., Nesteroff, 1973) and those of the deep basin model (e.g., Hsü, 1973; Ryan, 1973; Cita, 1973) as they were summarized by Drooger (1973b). Nevertheless, we draw attention to some other concepts that were only recently published. Drooger (1975) proposed a multi-Dead Sea model consisting of a series of subsiding depressions each less than 500 meters deep which were fed by an uninterrupted flow of Atlantic waters through the Gibraltar Gate. Following this concept, it is conceivable that evaporation reached a desiccation stage in every separate body of water without requiring a complete cessation of marine influx for the entire Mediterranean. Sonnenfeld (1975), a devoted advocate of the shallowbasin model, in addition to giving further support to Nesteroff's arguments, proposed that the Mediterranean supply faucet was not the Gibraltar Strait (which according to him remained a closed land-bridge during the Messinian) but instead far eastward to the sill that separated the Mediterranean from the Paratethys Lake system (Lac Mer).

In the following discussion we attempt to analyze the bearing of the sedimentary-tectonic model of the Saqiye Group on the desiccation problem within the framework of the eastern Mediterranean. We propose a shallow basin model which resembles the Nesteroff (1973) model. Morphologically, our model is similar to Drooger's (1975) multi-Dead Sea model and with respect to the water supply, our model relates to that of Sonnenfeld (1975). Most previous studies have utilized data from the western Mediterranean and its surrounding hinterland. However, the considerations applicable for the western Mediterranean are not necessarily valid for the eastern Mediterranean. The latter, which today has a different tectonic setting from that of the western 


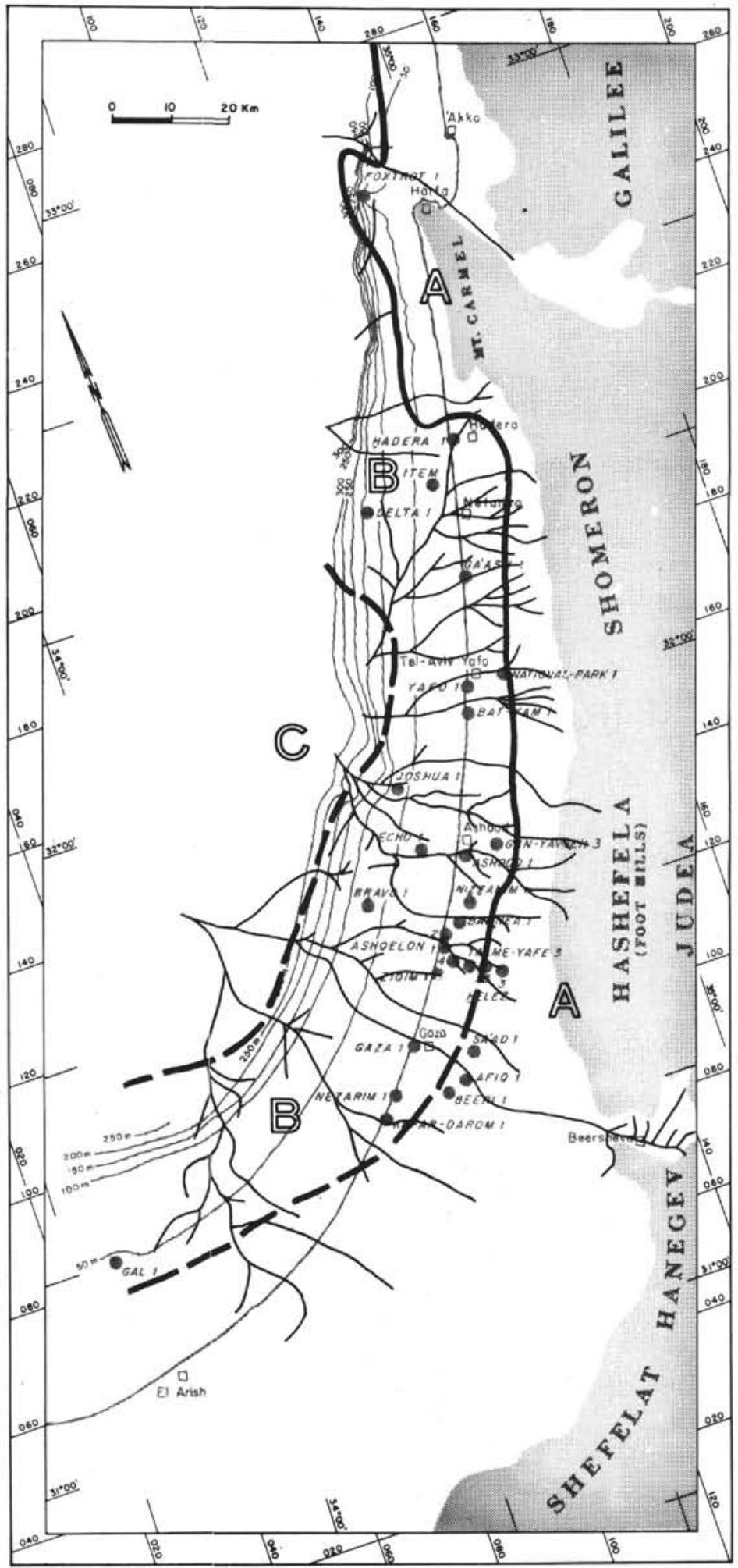

Figure 17. Reconstructed drainage pattern of the unconformity surface at the base of the Yafo Formation (Figure 16). Three geomorphological units are distinguished: (A) the Arabian Platform edge; $(B)$ the platform slope; $(C)$ the Levant Basin. The basin $(C)$ is characterized by flat topography ranging between -2250 meters to about -3000 meters, by tributaries of first and second order and by thalwegs of very low angle slopes. The platform slope (B), which is $20-35 \mathrm{~km}$ wide, is situated 
approximately between the -2250 and -500 meter contours and is drained by third and fourth order tributaries with steep thalwegs. The edge of the platform $(A)$ is cut by headward erosion of canyons with higher than fourth order tributaries.

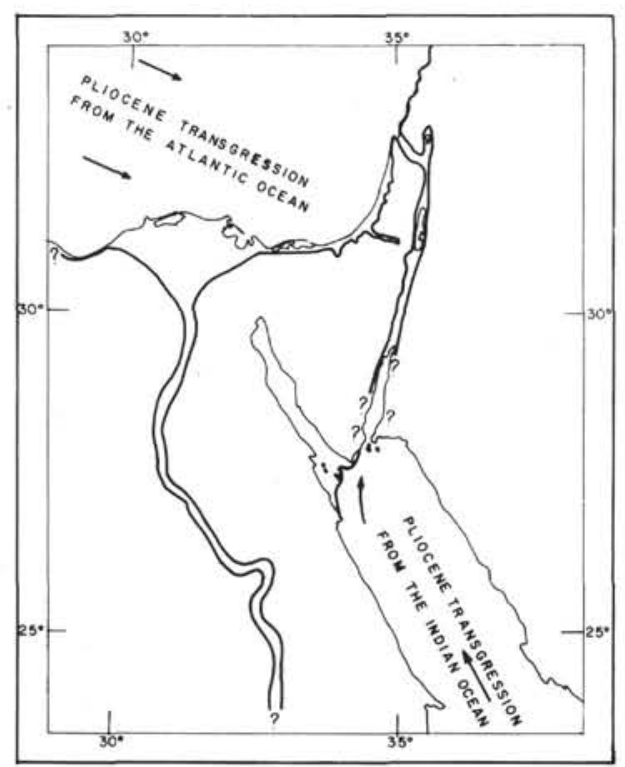

Figure 18. Reconstructed shorelines of the Pliocene transgression showing ingression of the sea into the deep gorge of the Nile River and the newly formed Jordan-Dead Sea Rift Valley. The connection between the Red Sea and the Jordan-Dead Sea embayment needs further elucidation.

Mediterranean, may also have been subjected to different tectonic and sedimentological processes during the Miocene.

\section{The Reconstructed Drainage System and Salt Lakes in the Eastern Mediterranean}

The paleogeographic reconstruction of the eastern Mediterranean is displayed in Figure 19. The region was bordered along its southern and eastern sides by the Arabian and African platforms and to the north by the orogenic Mediterranean Ridge (Mulder, 1973). The platforms were at least 2000 meters higher than the floor of the inner basin. Mount Eratosthenes rose some 1500 meters above the basin floor. It probably consists of ultrabasic igneous rocks, similar in composition to the Troodos Massif. In the areas now occupied by the Levant and the Herodotus abyssal plains, two giant salt lakes developed in which a great thickness of sodium and probably potassium salts accumulated. The boundaries of the lakes are defined on the basis of the distribution of seismic patterns which indicate salt deformation or diapirs, as shown on the maps of BijuDuval et al. (1974a, 1974b). The salt diapirs are also described by Neev et al. (1976) from the abyssal plains of the Levant and from both sides of the
Eratosthenes Seamount. Possibly the salt thickness reached $2-3 \mathrm{~km}$ as assumed occurred in the western Mediterranean. We believe that these lakes resembled the present-day Dead Sea, both in hydrographic and climatic characteristics. According to the maps of BijuDuval et al. (1974a, 1974b), we can assume that the northern side of the Mediterranean Ridge was occupied by other salt lakes: Iskenderun, Antalya, and Cilicia. On the elevated areas around the salt lakes, anhydrite of sabkha origin was deposited; in local depressions salt and anhydrite were deposited under subaqueous conditions. In Israel the sabkha evaporites developed continuously over the slope of the platform. Similarly, they probably developed along the coasts of Lebanon and Syria. According to Said (1973, 1975), Messinian anhydrite developed below the Nile Delta sediments.

The reconstructed pattern of the associated drainage system from the Arabian Platform into the Levant Basin (Gvirtzman, 1969a, 1970) shows a high degree of superposition between the various drainage systems in the Miocene and the younger drainage systems that developed up to the present-day systems. We therefore presume that the modern continental drainage system in the Levant area, at least from the water-divide seaward (pattern la on Figure 19), is basically the headwards continuation of the subsurface system in the coastal plain and the continental shelf area.

The reconstructed drainage system (Figure 19) shows the convergence of high-order distributaries (higher than fourth order) on the platform into distributaries of third and fourth order on the slope, and finally, into main channels of first and second order in the Levant Basin. It is also possible that these main channels entered the salt lakes through a series of alluvial aprons typical of desert landscapes. The drainage system of Wadi el-Arish in northern Sinai runs through a channel of third order and merges with the Gaza-Beer Sheva canyon into a second-order channel. The dendritic system of the central Coastal Plain in Israel merges into a second-order channel southwest of Tel Aviv, through a depression named by Neev et al. (1976) as the Palmahim Graben. The drainage system of northern Israel near Mount Carmel flows through a second-order channel to the Levant Basin. It is conceivable that all the above-mentioned second-order channels join into a principal first order river which drains into the Levant salt lake.

Similarly, the reconstructed Nile River (Said, 1973, 1975) flows in a canyon which was deeply incised into the platform edge, through the area which is today covered by the Pliocene-Pleistocene Nile Cone, and probably discharged into the Herodotus salt lake. We also presume, on the basis of subsurface data, that another drainage system in northwestern Sinai (west of the Bardawil lagoon), which is partly concealed by 


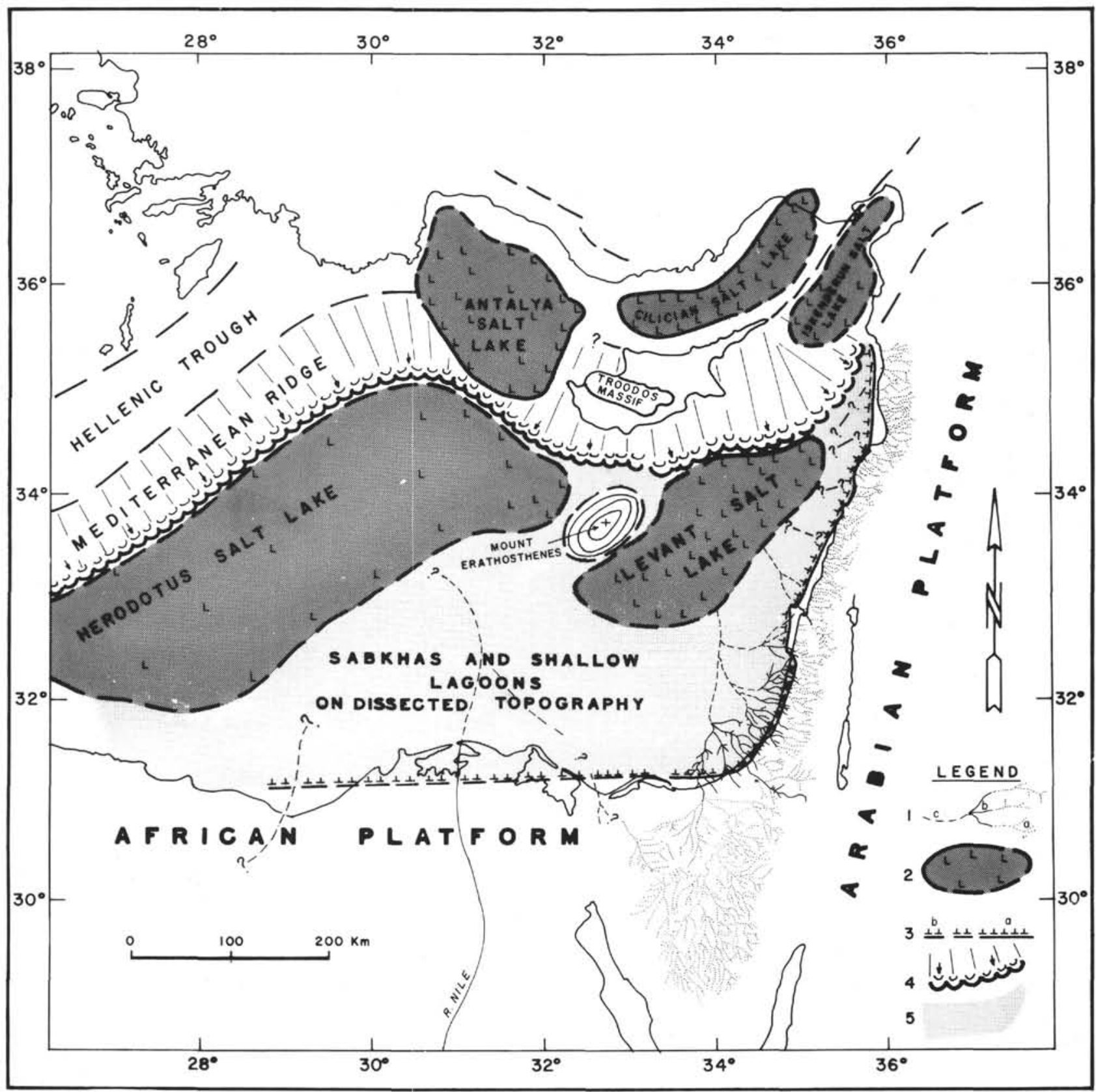

Figure 19. Paleogeographic map of the eastern Mediterranean during the end of the Messinian. (1) Reconstructed drainage pattern: (a) recent drainage system on the Arabian Platform; (b) reconstructed drainage system (from Figure 17); (c) postulated routes of the major channels in the basin area. (2) Salt lake; $L=$ salt diapirs (after Biju-Duval et al., 1974a; Biju-Duval et al., 1974b). (3) Edge of the Arabian Platform: (a) inferred; (b) hypothetical. (4) The thrust front of the orogenic belt of the Mediterranean Ridge (after Rabinowitz and Ryan, 1970; Ryan et al., 1970; Biju-Duval et al., 1974a; Biju-Duval et al., 1974b). (5) Desiccated plains of the eastern Mediterranean Basin, covered by anhydrite.

modern dune sands, flowed into the Nile channel and ultimately into the Herodotus salt lake. A possible connection between the eastern Mediterranean and the other western Mediterranean basins could have existed through the narrow strait, between the Mediterranean Ridge and the Cyrenaica coast.

In conclusion, the eastern Mediterranean should be regarded during Messinian times as a huge endorheic depression. Its floor was at least 2000 meters below the surrounding platforms, with the two large Levant and Herodotus salt lakes in the center. The arid climatic conditions enhanced the evaporation. The endorheic and climatic setup resembles that of the modern Dead Sea. Although the water level of the salt lakes is assumed to be 2000 meters below the surrounding platform, the elevation of the lake-surface level could have been near or a few hundred meters below, the global sea level at that time.

The Problem of the Vertical Tectonic Play of the Arabian Platform and the Levant Basin

The vertical "yo-yo" movements of the Arabian Platform since Miocene times relative to, or together with, the Levant Basin are reconstructed from the 
study of regional stratigraphy and applied to the problem of the depth of the eastern Mediterranean Levant Basin.

The post Bet Guvrin uplift, or the separation between the rising Arabian Platform and the Levant Basin occurred about 16 m.y.B.P., and was followed by the first erosional phase. The differential movement was greater than 1000 meters. The cessation of this movement was followed by slight subsidence which resulted in the transgression of the Ziqim sedimentary cycle. A later upward movement resulted in the termination of the Ziqim cycle, at about 9 m.y.B.P. The cumulative vertical rising of the platform from 16 to 9 m.y.B.P. was over 2000 meters. From this, one might calculate an average rate of the vertical movement of about 285 meters per million years, or about $0.3 \mathrm{~mm}$ per year. This vertical movement was accompanied by intensive erosion but not by evaporation, since neither the Levant Basin nor the rest of the Mediterranean was disconnected from the global oceanic system at this time.

A pre-Ziqlag subsidence in the range of about 2000 meters is assumed in order to account for the submerging of the platform below sea level. The subsidence must have included both the platform and the basin at this stage, since no differential fault movement has been detected. This subsidence occurred, according to rough estimation, during the time span of about 9 to 7 m.y.B.P. The average subsidence rate is therefore about 1000 meters per million years, or about $1.0 \mathrm{~mm}$ per year. The following regression, which entailed the deposition of the Mavqiim evaporites, could have happened either because of eustatic movements or isostatic movement, or a combination of both.

An isostatic model would imply that the platform and slope re-emerged above the global sea level at the same pace as the previous submergence, but in this case emergence was accompanied by the cut-off of the Mediterranean from the global oceanic system. The Levant Basin would then have been a depression with its floor slightly below global sea level and its eastern and southern borders lined by a series of scarps of the continental plateau 2000 meters above. This model required that continued subsidence of the Levant Basin occurred in order to provide room for the accumulating evaporites.

The eustatic model implies tectonic stability of the platform area and regression and resulting desiccation with the sea withdrawing from the platform because of the cut-off of the Mediterranean from the global oceans. The ultimate desiccation would have resulted in the formation of a 2000-meter deep depression below the platform level, practically 2000 meters below global sea level. This model does not call for the sinking of the floor of the Levant Basin since the room for the thick sequence of evaporites would have been provided by the existing deep basin.

The process responsible for the Pliocene-Yafo transgression can similarly be explained either by isostatic resubsidence of the platform at about the same rate as the previous emergence or by reflooding of the Mediterranean by its reconnection with the global oceans exclusive of any tectonic subsidence.
The two possible mechanisms for the desiccation and the subsequent flooding represent, in fact, two extreme end-members. It is very likely that the actual process involved the combination of both mechanisms with the dominance of either one or the other. In any event, we have to explain the post Bet Guvrin uplift and the pre-Ziqlag submergence of the Arabian Platform as a tectonic process. This sets a precedent for repetition of such isostatic play during the Messinian; though it does not prove such a movement. The mechanism for either a single or repeated isostatic movements is probably connected with the movement and the subduction of the Levant plate under the midMediterranean Ridge (Rabinowitz and Ryan, 1970; Mulder, 1973). Although Ryan (1973) does not accept the proposed subsidence rates of $1 \mathrm{~mm}$ per year because of geophysical considerations, the geological evidence from the eastern Mediterranean forces us to consider such rates. Note that geological and seismic evidence points to an intensive subsidence of the same order of magnitude and similar rate during the Pliocene and the Pleistocene (Neev et al., 1976).

\section{Considerations of Water and Salt Budgets}

Hsü (1973) presented, among his arguments for a deep-sea model, calculations of the water and salt volume in the Mediterranean during the Messinian desiccation. Hsü, on the basis of Lotze's (1957) data, estimated the total precipitation over the area of the Mediterranean Sea as $1200 \mathrm{~km}^{3}$ per year and the total river discharge as $200 \mathrm{~km}^{3}$ per year. Thus, the total input of $1400 \mathrm{~km}^{3}$ per year is smaller by $3300 \mathrm{~km}^{3}$ than the annual evaporation loss of $4700 \mathrm{~km}^{3}$ per year. The deficit is compensated by addition of seawater from the Atlantic Ocean through the Strait of Gibraltar. This balance calculation does not relate, however, to the water inflow from the Black Sea through the Bosphorus-Dardanelles Straits. Tixeront (1969) presented somewhat different water budget figures, taking into account the contribution from the Black Sea. However, his calculations also indicate a significant water deficit which is compensated for by an annual influx of nearly $1500 \mathrm{~km}^{3}$ from the Atlantic Ocean.

Hsü (1973) concluded that the closing of the Gibraltar Strait would result in complete desiccation within 1000 years and in the deposition of a continuous salt layer 20 meters thick. Since the brines are concentrated in separate salt basins which occupy about one third of the Mediterranean area, the resulting salt layer should be approximately 60 meters thick. Hence, in order to account for the Messinian salt accumulation estimated at 1 to 1.5 million $\mathrm{km}^{3}$, there is a need to refill and evaporate the Mediterranean 8-10 times.

There may, however, be additional sources of supply for the Messinian evaporites. The volume of brackish and fresh water supplied to the Messinian Mediterranean from the Paratethys lakes (Lac Mer) cannot be estimated because of the lack of volume and salinity data. However, it is likely that the flow from the Black Sea into the Mediterranean was much greater than the present amount of $190 \mathrm{~km}^{3}$ per year (Tixeront, 1969). The waters from the Paratethys, though lower in salinity, probably flowed through wider straits than the 
present Bosphorus and the Dardanelles, thereby allowing for greater replenishment. Furthermore, if we assume that the present-day inflow from the Black Sea continued over a period of 2 million years of the Messinian, even with a salinity of one third that of normal seawater, we can account for three times the volume of the Messinian evaporites deposited in the entire Mediterranean. The Mediterranean Ridge should not be considered as a major barrier to flow from the Paratethys since part of its orogenic rise postdates the Messinian (Mulder, 1973). Consequently, a large part of this inflow probably passed through the Mediterranean Ridge into the Levant Basin.

By our calculations, a small contribution of additional water can be expected from rivers feeding individual salt lakes. The possible contribution of the Nile River to the Herodotus Salt Lake (Figure 19) over a period of 2 million years-on the basis of a salinity estimation of $30 \mathrm{ppm} \mathrm{NaCl}$ (Data from Livingstone, 1963, table 58), and an annual discharge of about $100 \mathrm{~km}^{3} \mathrm{1}_{\text {-is }}$ about $6000 \mathrm{~km}^{3}$ of rock salt, about $2 \%-3 \%$ of the lake's total accumulation. ${ }^{2}$

The 1.5 million $\mathrm{km}^{3}$ of salt in the Mediterranean can also be attributed to the incomplete blocking of the Gibraltar Strait during the Messinian, allowing a continuous marine water input of $18.5 \mathrm{~km}^{3}$ per year. This flow rate is relatively small and could have resulted either from leakage through the Gibraltar Gate or from subsurface seapage of brines into the depression.

Taking these other sources into consideration, there is no need to assume the process of repeated filling and drying proposed by Hsü (1973). Drooger (1975) also proposed a continuous inflow through the Gibraltar Strait, and Sonnenfeld (1975) proposed a continuous supply from the Paratethys lakes. The arguments presented in this section are summarized as follows.

1) The assumption that the Gibraltar Strait is the exclusive or main source for the water and salt supply for the Messinian evaporites is oversimplified; it is not unequivocal for the entire Mediterranean and particularly not for the eastern Mediterranean.

2) There is no need to apply a mechanism of repeated ( 8 to 10 times) filling and drying. A continuous water supply from a marine or from a brackish reservoir, together with a minor discharge from rivers

\footnotetext{
${ }^{1}$ Hurst et al., 1946, showed that near Aswan the average annual flow-on the basis of 80 years of measurement-is about 83 million $\mathrm{km}^{3}$. However, Hipel et al., 1975, showed that during the 32 years before the construction of the first dam in 1902, the annual average flow was $106 \mathrm{~km}^{3}$, and after its construction it dropped considerably. For the purpose of the calculation of the water discharge, the natural flow before the construction of the dam is taken into account. The annual loss due to evaporation and percolation down-stream from Aswan is estimated by Dekker, 1972, as $6 \mathrm{~km}^{3}$. Hence, the net discharge of the Nile is about $100 \mathrm{~km}^{3}$ per year. Although the Messinian climate was arid, the ancient Nile as well as the modern Nile were not affected as their water supply is derived from a humid tropical zone.

${ }^{2}$ The Herodotus Salt Lake occupies roughly one fifth of the total area of the Mediterranean salt lakes and therefore should contain approximately $0.2-0.3$ million $\mathrm{km}^{3}$ of salt.
}

like the Nile, could have accounted for the Messinian evaporites.

3) The salt lakes in the Mediterranean could have existed continuously in equilibrium with an influx from the drainage systems and loss by evaporation. The miniature example of the Jordan-Dead Sea catchment area in the Rift Valley (Neev and Emery, 1967) which has been in existence since the early Pleistocene, is a parallel model.

The issue of the salt and the water balance is not relevant to the problem of deep or shallow basin model; it does not support or reject either of the two hypotheses.

\section{The Marine Intercalations Within the Evaporite Sequence}

The normal marine intercalations within the Messinian evaporitic sequence are well known throughout the entire Mediterranean area (e.g., Schreiber and Friedman, 1976). There are two alternative explanations for these intercalations.

1) A model relating to the opening and closing of the Strait of Gibraltar was proposed by Hsü et al. (1973) and Hsü (1973). This explanation is derived from the model of repeated filling and drying, wherein each marine intercalation represents a new refill through the Gibraltar Gate. Hsü and other authors believe there is a reasonable correlation between the marine intercalation in the Messinian sequence of Sicily and the 8 to 10 marine refilling cycles during the Messinian time. The following is implied from this model. (1) Every marine intercalation and every interbedded evaporitic layer is practically synchronous over the entire Mediterranean basin. (2) Each marine intercalation and evaporitic layer continuously paved the topography of the basin from its elevated margins down to its floor. (3) A good correlation should exist between the number of marine intercalations and their individual characteristics in different and remote localities in the Mediterranean basin.

2) The alternative explanation relates the Messinian regression and desiccation in the eastern Mediterranean with the tectonic uplift of the surrounding platforms. This model calls for one continuous regression with the marine intercalations representing oscillations in sea level during the regression. The higher marine intercalations at the edge of the platform would, accordingly, have been formed first, and the lower intercalations in the basin would have been formed last. The whole sequence of the marine intercalations probably represents deposition at an early stage of the Messinian event. The later stage was probably marked by the isolation of the Mediterranean from the global ocean system and was characterized by only evaporite deposition in the salt lakes in the central basins. The following is implied from this model. (1) During regression the salinity of the seawater remained more or less normal which allowed the presence of marine plankton and the potential of depositing bioclastic limestones along the shoreline. The evaporites accumulated only along coastal sabkhas and sea marginal 
flats. Any interruption in the regressive tendency either as a result of local small-scale eustatic or isostatic movements caused a short-term marine ingression and deposition of a marine intercalation within the evaporite sequence. (2) The marine intercalations are not synchronous over the entire basin. The number of the intercalations at different localities is not constant. The proposed model requires diachronous relationships; the intercalations on the upper flanks of the basin must be older than those on the lower topography.

The marine intercalations of the Mavqiim Formation were found in most boreholes in Israel either on the upper part or the lower part of the slope. They contain normal marine or hypersaline foraminiferal assemblages. Their number is not constant. Neither is there any correlation in their stratigraphic position and characteristics between the boreholes in the upper part of the slope (e.g., Gan Yavneh, Figure 8; Talme Yafe 3 , Figure 9) and the boreholes on the relatively lower part of the slope such as Ashqelon 4, Ashqelon 1 (Figure 9), Yafo 1, Ashdod 1 (Figure 7), Joshua 2 and Echo 1 (Figure 6). It is therefore likely that the evaporites, including the marine intercalations, are diachronous: the oldest are on the platform edge, (e.g., Beeri SH-4), and the youngest are on the lower slope and in the Levant Basin. Therefore we prefer the second alternative. The salts were deposited under Dead Sea-like conditions in endorheic arid depressions. A continuous input of waters and salts, mostly from the Paratethys lakes, was compensated by intensive evaporation. Under nearly equilibrium conditions the lakesurface levels could have been more or less preserved in the depressions, always below the global sea level.

\section{Conclusions: Proposed Shallow-Basin Model}

The local evidence from the eastern Mediterranean led us to prefer a shallow basin model. We believe that the tectonic or isostatic model is preferable to the model of repeated filling and drying. The marine intercalations in the Mavqiim Formation, which seem to be diachronous, are evidently the result of oscillations in the course of a single continuous regression and not the result of synchronous marine refill of the entire Mediterranean Basin.

We divide the Messinian history into two stages. The first stage is characterized by a continuous, yet oscillatory, regression. The Arabian and African platforms and probably other surrounding platforms were elevated hundreds to thousands of meters above the global sea level. Their pre-existing canyons were rejuvenated and paved by nodular anhydrite of coastal sabkha origin on sea marginal flats. In the central basins relatively shallow marine deposition prevailed with a possible connection to the global ocean system, allowing planktonic foraminifera to thrive.

The second stage started with the isolation of the Mediterranean from the global ocean system which resulted in the formation of the salt lakes in the depressions. The salt basins could have been lower than the ocean level but not necessarily very deep. The basins were very similar to the Dead Sea or to other depressions like Qattara, Dakhla, and Farafra in Egypt. Drooger (1975) suggested a similar "multiDead Sea model" with a periodic normal marine layer at the water's surface. He attributed the marine intercalations to the existence of the normal-marine surface layer. Our data, however, neither support nor reject the existence of an overriding normal marine water layer.

The conditions for the continuous existence of the salt lakes during the second Messinian stage include the following. (1) The salt basins remain cut off from the ocean. (2) The continuous subsidence keeps pace with, or is faster than, the evaporite accumulation. (3) There is a continuous water supply, either marine or fresh, from other continental lakes, rivers, or seepages of brines derived from seawater. (4) The climatic conditions are such that evaporation considerably exceeds precipitation and replenishment.

The prevalence of these conditions over a considerable period of time can account for the accumulation of thousands of meters of salt. We believe that these two stages, regression and desiccation, happened during the Messinian, 7-5 m.y.B.P., although the duration of each stage is not yet clear.

The hypothesis of the existence of a very deep, yet dry, hole in the earth's crust at the Mediterranean Basin, as suggested by Hsü et al. (1973), does not necessarily agree with the available data from the eastern Mediterranean.

\section{ACKNOWLEDGMENTS}

This paper constitutes part of the results of Research Project No. 29371, conducted at the Geological Survey of Israel.

We extend special thanks to Miss Laura Ordan for her editing assistance and helpful remarks and to Mr. Amihai Sneh who critically read the manuscript and offered many useful remarks and suggestions. We also thank Dr. Yehezkeel Druckman, Dr. David Neev, Dr. Guido Martinotti, and Dr. Shimon Moshkovitz, for their comments. Thanks are due to Mrs. Beverly Katz for typing the manuscript, and to $\mathrm{Mr}$. Aryeh Peer, Mr. Saadyah Levi, and Mrs. Carmella Hadar for drafting the illustrations. We also thank Oil Exploration (Investments) Ltd. and Sonol Israel Ltd. for permission to publish the drillhole and seismic data.

\section{REFERENCES}

Avnimelech, M., 1936. Etudes géologique dans la region de la shephela en Palestine. Trav. Lab. Geol. Univ. Grenoble, v. 20 , p. 1-144.

Avnimelech, M., 1966. Miocene pteropoda-facies in Israel and the neighbouring countries. 3rd Session of Committee on Mediterranean Neogene Stratigraphy, Proc. Bern, Leiden, E. J. Brill, p. 308-311.

Ball, M. W. and Ball, D., 1953. Oil prospects of Israel. Am. Assoc. Petrol. Geol. Bull., v. 37, p. 1-113.

Bein, A., 1974. Reef development in the Judea Group from the Carmel and the Coastal Plain, Israel. Ph.D. Thesis, Hebrew University, Jerusalem, 193 p. (Hebrew, with English abstract).

Bein, A. and Weiler, Y., 1976. The cretaceous Talme-Yafe Formation: a contour current shaped sedimentary prism of calcareous detritus at the continental margin of the Arabian Craton. Sedimentology, v. 23. p. 511-532. 
Berggren, W. A., 1972. A Cenozoic time-scale-some implications for regional geology and paleobiogeography. Lethaia, v. 5 , p. $195-215$.

Berggren, W. A. and Van Couvering, J. A., 1974. The Late Neogene: biostratigraphy, geochronology and paleoclimatology of the last 15 million years in marine and continental sequences. Paleogeogr., Paleoclimatology, Paleoecol., v. 16 , p. 1-216.

Biju-Duval, B., Courrier, P., Apostolescu, V. and Letouzey, J., 1974a. Carte géologique et structurale de basins tertiaires du domaine Méditerranéen, 1:2,500,000, en 2 coupures. Institut Français du Pétrole et Centre National pour l'Exploitation des Océans., Paris. Technip.

Biju-Duval, B., Letouzey, J., Montadert, L., Courrier, P., Mugniot, J. F., and Sancho, J., 1974b. Geology of the Mediterranean Sea basins, In Burk, C. A. and Drake, C. (Eds.), The geology of continental margins, Berlin, Heidelberg, New York, (Springer-Verlag); p. 695-721.

Blow, W.H., 1969. Late Middle Eocene to Recent planktonic foraminiferal biostratigraphy. 1st Intern. Congr. Plankt. Microfossils Proc., Geneva, 1967, v. 1, Bronnimann, P. and Renz, H. H. (Eds.), Leiłen, Brill. p. 199-475.

Buchbinder, B., 1971. Tertiary oil prospects of the western Coastal Plain and offshore areas, Israel: Geol. Surv. Israel and Inst. Petrol. Res. Geophysics, Internal Rept. p. 19. 1975a. Lithogenesis of Miocene reef limestones in Israel with particular reference to the significance of the red algae. Geol. Surv. Israel, Rept. OD/3/75, 173 p. 1975b. Stratigraphic significance of the alga $\mathrm{Am}$ phiroa in Neogene-Quaternary bioclastic sediments from Israel: Israel J. Earth-Sci., v. 24, p. 44-48.

Chevalier, J. P., 1961. Les Madréporaires du Pliocene d'Orosei (Nuoro, Sardaigne): Bull. Soc. Geol. France, v. 3, p. $266-270$.

Chumakov, I. S., 1967. Pliocene and Pleistocene deposits of the Nile Valley in Nubia and Upper Egypt. Geol. Inst. Acad. Sci., USSR, Trans. v. 170, p. 1-110 (Russian).

1973. Geological history of the Mediterranean at the end of the Miocene-the beginning of the Pliocene according to new data, In Ryan, W. B. F., Hsü K. J., et al., Initial Reports of the Deep Sea Drilling Project, Volume 13, Washington, (U.S. Government Printing Office), p. 1241-1243.

Cita, M. B., 1973. Mediterranean evaporite: paleontological arguments for a deep-basin desiccation model. In Drooger, C. W. (Ed.), Messinian events in the Mediterranean: Amsterdam, London, (North Holland Publ. Co.), p. 206228.

Cox, L. R., 1934. On the occurrence of marine Oligocene in Palestine: Geol. Mag., v. 71, p. 337-355.

Dekker, G., 1972. A note on the Nile: Water Resources Res., v. 8 , p. $818-828$.

Derin, B. and Reiss, Z., 1973. Revision of marine Neogene stratigraphy in Israel: Israel J. Earth-Sci., v. 22, p. 199210.

Drooger, C. W., 1973a (Ed.). Messinian events in the Mediterranean. Geodynamic Scientific Report No. 7 on the Colloquium held in Utrecht March 2-4, 1973. Amsterdam, London, (North Holland Publ. Co.), 272 p.

1973b. The Messinian events in the Mediterranean: a review. In Drooger, C. W. (Ed.), Messinian events in the Mediterranean: Amsterdam, London (NorthHolland Publ. Co.), p. 263-272.

1975. The Late Miocene Mediterranean. In Progress in geodynamics: Amsterdam (Royal Netherlands Academy of Arts and Science), p. 119-125.

Druckman, Y., Gvirtzman, G., and Kashai, E., 1975. Distribution and environments of deposition of Upper Triassic on the northern margins of the Arabian Shield and around the Mediterranean Sea: Ninth Intern. Congr. Sedimentol. Proc., Nice, Thème 5, v. 1, p. 183-192.

Friedman, G. M., 1973. Petrographic data and comments on the depositional environments of the Miocene sulfates and dolomites at Sites 124, 132, and 134, western Mediterranean Sea. In Ryan, W. B. F., Hsü, K. J., et al. Initial Reports of the Deep Sea Drilling Project, Volume 13: Washington (U.S. Government Printing Office), p. 695708.

Ginzburg, A., 1971. Offshore Israel, interpretation of seismic reflection survey. Prepared for Belpetco Israel Ltd., Inst. Petrol. Res. Geophys., Rep. RS/916-0/71, 17 p.

Ginzburg, A., Cohen, S. S., Hay-Roe, H., and Rosenzweig, A., 1975. Geology of the Mediterranean Shelf of Israel: Am. Assoc. Petrol. Geol. Bull., v. 59, p. 2142-2160.

Grader, P., 1958. Geological history of the Heletz-Brur area, Israel. Part 1-Upper Cretaceous-Quaternary: Geol. Surv. Israel Bull. 22, 15 p.

Grader, P. and Gvirtzman, G., 1961. Neogene gas prospects in the central Coastal Plain, Israel: Bull. Res. Counc. Israel, v. 10G, p. 147-172.

Greenfield, L. L. and Bino, Z., 1974. A seismic interpretation of the southern Coastal Plain of Israel: Inst. Petrol. Res. Geophys. Rept. S1/761/70, 887/71, 982/72, 48 p.

Gvirtzman, G., 1969a. The Saqiye Group (Late Eocene to Early Pleistocene) in the Coastal Plain and Hashephela regions, Israel, v. 2-Maps: Geol. Surv. Israel Bull. no. 51 (37 maps).

1969b. Subsurface data on the Saqiye Group (Late Eocene to Early Pleistocene) in the Coastal Plain and Hashephela regions, Israel: Geol. Surv. Israel, Rept. OD/ $1 / 69,180 \mathrm{p}$.

1970. The Saqiye Group (Late Eocene to Early Pleistocene) in the Coastal Plain and Hashephela regions, Israel: Geol. Surv. Israel, Rept. OD/5/67, 180 p. (Hebrew, English summary).

Gvirtzman, G. and Buchbinder, B., 1969. Outcrops of Neogene formations in the central and southern Coastal Plain, Hashephela and the Beer Sheva' regions, Israel: Geol. Surv. Israel Bull. 50, 76 p.

Gvirtzman, G. and Klang, A., 1972. A structural and depositional hinge-line along the Coastal Plain of Israel, evidenced by magneto-tellurics: Geol. Surv. Israel Bull. 55, $18 \mathrm{p}$.

Gvirtzman, G. and Reiss, Z., 1965. Stratigraphic nomenclature in the Coastal Plain and Hashephela regions: Geol. Surv. Israel, Rept. OD/1/65, 14 p.

Hipel, K. W., Lennox, W. C., Unny, T. E. and McLeod, A. I., 1975. Intervention analysis in water resources: Water Resources Res. v. 11 , p. $855-861$.

Hsü, K. J., 1973. The desiccated deep basin model for the Messinian events. In Drooger, C. W. (Ed.), Messinian Events in the Mediterranean: Amsterdam, London (North-Holland Publ. Co.), p. 60-67.

Hsü, K. J., Cita, M. B., and Ryan, W. B. F., 1973. The origin of the Mediterranean evaporites. In Ryan, W. B. F., Hsü, K. J., et al., Initial Reports of the Deep Sea Drilling Project, Volume 13: Washington (U.S. Government Printing Office), p. 1203-1232.

Hurst, H. E., Black, R. P., and Simaika, Y. M., 1946. The Nile Basin, the future conservation of the Nile, Physical Dept. Paper 51, Ministry of Public Works, Cairo, Egypt.

Issar, A., 1961. Geology of the subsurface water resources of the Shefela and Sharon areas. Tahal Water Planning for Israel Ltd., Publ. No. P.M. 307, 143 p. (Hebrew). 
Kashai, E., 1973. Exploration drilling program for the Gaza sand: Lapidoth, Israel Oil Prospectors Corp. Ltd., Rept., Tel Aviv, 6 p.

Livingstone, D. A., 1963. Chapter G. Chemical composition of rivers and lakes. In Fleischer, M. (Ed.), Data of Geochemistry, sixth ed. U.S. Geol. Surv., Prof. Paper 440G, 64 p.

Lotze, F., 1957. Steinsalz und Kalisalz: Berlin (Borntraeger), p. 465 .

Lowengart, S., 1927. The groundwater of the Palestine Coastal Plain: Construction and Industry, no. 5-6, Tel Aviv, p. 13-14.

Martinotti, G. M., 1973. Miogypsina in the Gaza 1 well, Coastal Plain, Israel: Geol. Surv. Israel Bull. 57, 6 p.

Moshkowitz, S., 1963. The mollusca in the upper part of the "Sakiebeds" (upper Neogene-lower Pleistocene) in the central coastal plain of Israel: Israel J. Earth Sci., v. 12, p. 97-146.

, 1968. The mollusca in the marine Pliocene and Pleistocene sediments of the southeastern Mediterranean Basin (Cyprus-Israel): Ph.D. Thesis, The Hebrew University, Jerusalem.

Mulder, C. J., 1973. Tectonic framework and distribution of Miocene evaporites in the Mediterranean. In Drooger, C. W. (Ed.), Messinian events in the Mediterranean: Amsterdam, London (North-Holland Publ. Co.), p. 44-59.

Nachmias, J., 1969. Source rocks of the Saqiye Group sediments in the Coastal Plain of Israel-a heavy mineral study: Israel J. Earth-Sci., v. 18, p. 1-16.

Neev, D., 1960. A pre-Neogene erosion channel in the southern Coastal Plain of Israel: Geol. Surv. Israel Bull. 25, $20 \mathrm{p}$.

Neev, D. and Emery, K. O., 1967. The Dead Sea, depositional processes and environments of evaporites: Geol. Surv. Israel Bull. 41, p. 1-147.

Neev, D., Almagor, G., Arad, A., Ginzburg, A., and Hall, J. K., 1973. The geology of the southeastern Mediterranean Sea: Geol. Surv. Israel, Rept. MG/73/5, 43 p.

1976. The geology of the southeastern Mediterranean: Geol. Surv. Israel Bull. 68, 52 p.

Nesteroff, W. D., 1973. Mineralogy, petrography, distribution and origin of the Messinian Mediterranean evaporites, In Ryan, W. B. F., Hsü, K. J., et al., Initial Reports of the Deep Sea Drilling Project, Volume 13: Washington (U.S. Government Printing Office), p. 673-694.

Perath, I., 1965. Microfaunas of the Jaffa 1 well, benthonic foraminifera. Oil Companies Micropaleontol. Lab., Rept. OS/4/65, Jerusalem, 23 p.

Petrocana, 1965. Ashdod area, continental shelf, Israel, evaluation from seismograph data. Calgary, Alberta, Canada (A. E. Pallister Consultants Ltd.) (unpublished).

Picard, L., 1959. Geology and oil exploration of Israel: Bull. Res. Counc. Israel, v. G8, p. 1-42.

Picard, L. and Solomonica, P., 1936. On the geology of the Gaza-Beersheba district. J. Pales. Orient. Soc., v. 16, p. 180-223. (Also in Bull. Geol. Dept., Hebrew Univ., Jerusalem, v. 1, no. 2, 44 p.)

Pomerancblum, M., Neev, D., and Reiss Z., 1962. Sedimentological analyses of "Sakiebeds" in Beeri core-hole no. 1 ("Sulfur"). Geol. Surv. Israel, Rept. Rec/1/62, 39 p.
Rabinowitz, P. D. and Ryan, W. B. F., 1970. Gravity anomalies and crustal shortening in the eastern Mediterranean. Tectonophysics, v. 10, p. 585-608.

Reiss, Z., 1968. Planktonic foraminiferids, stratotypes and a reappraisal of Neogene chronostratigraphy in Israel: Israel J. Earth-Sci., v. 17, p. 153-169.

Reiss, Z. and Gvirtzman, G., 1962. Subsurface Neogene stratigraphy of the Israel Coastal Plain: Geol. Surv. Israel, Rept. Pal/4/62.

1966a. Subsurface Neogene stratigraphy of Israel. Third Session of Committee on Mediterranean Neogene Stratigraphy Proc., Bern: Leiden, E. J. Brill, p. 314-346.

1966b. Borelis from Israel: Ecolg. Geol. Helv., v. 59, p. $437-447$.

Rothmann, S., 1967. Miocene mollusca of the Lakhish area, Central Israel: Israel J. Earth-Sci., v. 16, p. 140-164.

Ryan, W. B. F., 1973. Geodynamic implication of the Messinian crisis of salinity. In Drooger, C. W. (Ed.), Messinian events in the Mediterranean: Amsterdam, London (North-Holland Publ. Co.), p. 26-38.

Ryan, W. B. F., Cita, M. B., Dreyfus Rawson, M., Burckle, L. H., and Saito, T., 1974. A paleomagnetic assignment of Neogene stage boundaries and the development of isochronous datum planes between the Mediterranean, the Pacific and the Indian oceans in order to investigate the response of the world ocean to the Mediterranean "salinity crisis'”. Riv. Ital. Paleont., v. 80, p. 631-638.

Ryan, W. B. F., Hsü, K. J., et al. 1973. Initial Reports of the Deep Sea Driling Project, Volume 13: Washington (U.S. Government Printing Office).

Ryan, W. B. F., Stanley, D. J., Hersey, J. B., Fahlquist, D. A., and Allan, T. D., 1970. The tectonics and geology of the Mediterranean Sea. In Maxwell, A. (Ed.), The Sea, v. 4, pt. 2: New York, (Wiley-Interscience), p. 387-492.

Said, R., 1962. The geology of Egypt: Amsterdam-New York (Elsevier Publ. Co.), p. 377. 1973. The geological evolution of the River Nile. Pre-conference print-Intern. conference of northeast African and Levantine Pleistocene prehistory. Southern Methodist Univ., Dallas, Texas, 5-8.12.73, pt. I, p. 1-62; pt. II, p. 63-128; pt. III, tables and figure captions.

1975. The geological evolution of the River Nile. In Wendorf, F. and Marks, A. E. (Eds.), Problems in prehistory: North Africa and the Levant: Dallas (Southern Methodist Univ. Press), p. 7-44.

Schreiber, B. C. and Friedman, G. M., 1976. Depositional environments of Upper Miocene (Messinian) evaporites of Sicily as determined from analysis of intercalated carbonates: Sedimentology, v. 23, p. 255-270.

Shearman, D. J., 1966. Origin of marine evaporites by diagenesis: Inst. Mining Metallurgy (Newcastle-uponTyne) Trans., v. 75 , p. 208-215.

Sonnenfeld, P., 1975. The significance of Upper Miocene (Messinian) evaporites in the Mediterranean Sea: J. Geol., v. 83 , p. $287-311$.

Tixeront, J., 1969. Le bilan hydrologique de la mer noire et de la mer méditerranée: Internat. Assoc. Sci. Hydrol. Bull, p. 61-69. 